PAULA LUCIANA DE MENEZES

\title{
IMPACTO DAS ESPÉCIES DE RESPONSABILIDADE CIVIL SOBRE A LIBERDADE DE IMPRENSA
}

\author{
Dissertação de Mestrado
}

Orientadora: professora titular doutora Silmara Juny de Abreu Chinellato

UNIVERSIDADE DE SÃO PAULO

FACULDADE DE DIREITO

São Paulo

2018 



\section{IMPACTO DAS ESPÉCIES DE RESPONSABILIDADE CIVIL SOBRE A LIBERDADE DE IMPRENSA}

Dissertação apresentada à Banca
Examinadora do Programa de Pós-
Graduação em Direito da Faculdade de
Direito da Universidade de São Paulo,
como exigência parcial para obtenção do
título de Mestre em Direito, na área de
Concentração Direito Civil, sob orientação
da professora titular doutora Silmara Juny
de Abreu Chinellato.

UNIVERSIDADE DE SÃO PAULO

FACULDADE DE DIREITO

São Paulo

2018 
[FICHA CATALOGRÁFICA] 
Nome: MENEZES, Paula Luciana de.

Título: Impacto das espécies de responsabilidade civil sobre a liberdade de imprensa.

Dissertação apresentada à Faculdade de Direito da Universidade de São Paulo como exigência parcial para obtenção do título de Mestre em Direito.

Aprovada em:

Banca Examinadora

Prof. dr.

Instituição:

Julgamento:

Assinatura:

Prof. dr.

Instituição:

Julgamento:

Assinatura:

Prof. dr.

Instituição:

Julgamento:

Assinatura: 

Dedico esta dissertação de mestrado à minha família: àquela de onde vim, porto seguro, meus pais e meus irmãos, Paulo, Beth, Fernanda e Raoni; e àquela que eu escolhi (e pela qual também fui escolhida), ou seja, ao meu marido, Alex, e, especialmente, às minhas filhas, Juliana e Clara, que me proporcionaram paz de espírito e ao mesmo tempo impuseram maiores desafios para a realização deste trabalho. Também dedico este humilde trabalho acadêmico àqueles que, por meio da narrativa de fatos, da tessitura de críticas, da busca e da divulgação da informação, se dedicam a contribuir para a consciência política e social de todos nós, cidadãos, por meio da ampla divulgação de suas ideias. 



\section{AGRADECIMENTOS}

Agradeço a todos aqueles que contribuíram para que eu chegasse até aqui. Agradeço aos meus pais e aos meus irmãos, que contribuíam, não só com os recursos financeiros durante a juventude, mas também, e principalmente, com o suporte emocional ao longo da vida. Agradeço também ao meu marido, especialmente pela paciência e pelos exemplos de profissionalismo e dedicação. Agradeço às minhas filhas por suportarem as ausências e encherem de alegrias os momentos de presença.

Não posso deixar de agradecer àqueles que despertaram meu apreço pelo estudo dos temas da responsabilidade civil e da liberdade de imprensa: os amigos que fiz durante o estágio no Banco Itaú e aqueles que fiz (e desfiz) advogando no escritório Lourival J. Santos Advogados. E agradeço também a todos os que estiveram presentes desde o início e ao longo da minha empreitada acadêmica, me ajudando e me incentivando. À professora doutora Sonia Maria D'Elboux, orientadora do meu primeiro trabalho acadêmico, aos amigos que de alguma forma participaram do processo de construção desta dissertação, ajudando, criticando, incentivando e até mesmo suportando minhas ausências, Anna Figueiredo, Atalá Correa, Carlos Bentivegna, Fernando Speck, Flávia Novais Vernalha, Marina Souza, Marco Sabino, Marta Castro, Paula Beatriz, Priscila Furgeri, Raphael Neves, Rodrigo de Meo, Thyago Cruz e amigos de Mello Advogados. E, como não poderia deixar de ser, meu agradecimento especial ao professor Antonio Carlos Morato, pelas conversas e pelas contribuições, e, claro, à minha orientadora, professora Silmara Juny de Abreu Chinellato, por todo o incentivo e por todo o aprendizado compartilhado. 

De todas as liberdades é a da imprensa a mais necessária e a mais conspícua; sobranceira e reina entre as mais. Cabe-lhe, por sua natureza, a dignidade inestimável de representar todas as outras; sua importância é tão incomparável que, entre os anglos saxônicos, os melhores conservadores e os melhores liberais do mundo, sempre foi gêmea do governo representativo a crença de que não se pode levantar a mão contra a liberdade de imprensa, sem abalar a segurança do Estado.

Rui Barbosa 



\section{RESUMO}

MENEZES, Paula Luciana de. Impacto das espécies de responsabilidade civil sobre a liberdade de imprensa. 2018. 205 f. Dissertação (Mestrado) - Faculdade de Direito, Universidade de São Paulo, São Paulo, 2018.

Trata-se de dissertação que tem como objetivo analisar a evolução da responsabilidade civil e da liberdade de imprensa para então verificar quais são os impactos da aplicação das diferentes modalidades de responsabilidade civil na liberdade de imprensa quando esta comete abusos contra os direitos da personalidade. Para tanto, faz-se uma análise sobre as diferentes teorias da culpa e sobre as críticas a elas desenvolvidas, alcançando as teorias do risco, suas críticas e sua atual aplicação, especialmente após a promulgação do atual Código Civil brasileiro, que conta com o artigo 927, parágrafo único, considerado uma cláusula geral de responsabilidade civil com fundamento no risco da atividade. Em seguida, faz-se uma análise da evolução da imprensa e da própria liberdade de imprensa no mundo e especialmente na legislação brasileira. A união dos dois temas se dá a partir da análise jurisprudencial acerca da aplicação da responsabilidade civil aos abusos cometidos pela imprensa contra os direitos da personalidade ao longo do tempo, para então se chegar a uma conclusão sobre qual seria a mais adequada modalidade de responsabilização civil da imprensa e dos meios de comunicação em geral quando estes violam os direitos da personalidade.

Palavras-chave: Direito. Direito civil. Responsabilidade civil. Imprensa. Liberdade de imprensa. Responsabilidade subjetiva da imprensa. Responsabilidade objetiva da imprensa. 



\begin{abstract}
MENEZES, Paula Luciana de. Impact of Civil Liability on Freedom of the Press. 2018. 205 p. Dissertation (Master) - Law School, University of São Paulo, São Paulo, 2018.

The purpose of this dissertation is to analyze the evolution of civil liability and freedom of the press, in order to verify the impact of the application of the different modalities of civil liability in the freedom of the press when it commits abuses against the rights of the personality. In order to do so, an analysis is made of the different theories of guilt and the criticisms developed around them, reaching the theories of risk, their criticism and nowadays application, especially after the promulgation of the current Brazilian Civil Code, and its Article 927, sole paragraph, considered a general liability clause based on the risk of the activity. Then, an analysis is made of the evolution of the press and of the freedom of the press in the world, especially in Brazilian legislation. The union of the two themes is based on the jurisprudential analysis of the application of civil liability to the abuses committed by the press against the personality rights over time, to reach the conclusion of which would be the most appropriate modality of civil liability the press and the media in general, when they violate the rights of the personality.
\end{abstract}

Keywords: Law. Civil right. Civil liability. Press. Freedom of the press. Liability of the press. Strict liability of the press. 



\section{SUMÁRIO}

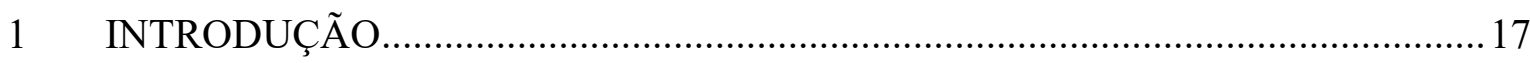

2 A RESPONSABILIDADE CIVIL EXTRACONTRATUAL ...................................2

2.1 A evolução histórica da responsabilidade civil extracontratual ................................23

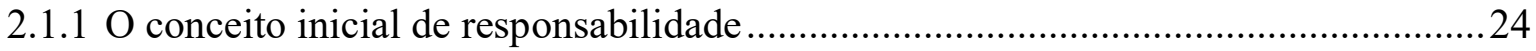

2.1.2 A evolução da responsabilidade civil extracontratual baseada na culpa ....................27

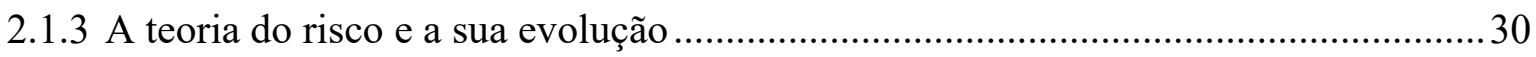

2.2 A responsabilidade civil extracontratual no ordenamento jurídico brasileiro: do Código Civil de 1916 até a Constituição Federal de 1988 ...........................................36

2.3 A Constituição Federal de 1988: A teoria do risco no ordenamento brasileiro e o Código Civil de 2002

2.4 As críticas ao artigo 927, parágrafo único, do Código Civil e as diversas teorias do risco

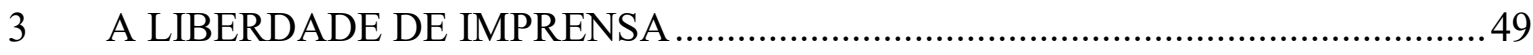

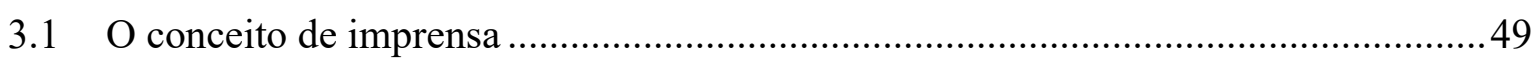

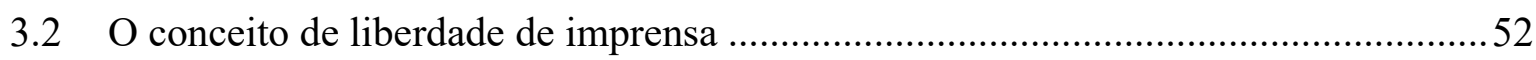

3.3 A evolução e a importância da liberdade de imprensa ...............................................53

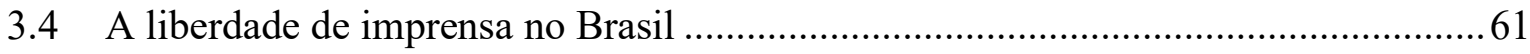

4 A RESPONSABILIZAÇÃO DA IMPRENSA PELOS ABUSOS COMETIDOS CONTRA OS DIREITOS DA PERSONALIDADE ….......................................... 71

4.1 O conflito entre a liberdade de imprensa e os direitos da personalidade ...................71

4.2 A responsabilização da imprensa pelos abusos cometidos: do período colonial até a vigência da Lei $n^{\circ} 2.883 / 1953$

4.3 A responsabilização da imprensa pelos abusos contra os direitos da personalidade na vigência da Lei ${ }^{0}$ 5.250/1967.

4.4 A responsabilização da imprensa pelos abusos contra os direitos da personalidade após a Constituição Federal de 1988

4.5 A Lei de Imprensa e o julgamento da Arguição de Descumprimento de Preceito Fundamental $n^{\circ} 130-7$. 
4.6 Breves considerações sobre a responsabilização da imprensa pelos abusos contra os direitos da personalidade nos Estados Unidos.

5 A APLICAÇÃO DA RESPONSABILIDADE CIVIL AOS ABUSOS COMETIDOS PELA IMPRENSA CONTRA OS DIREITOS DA PERSONALIDADE

5.1 A aplicação da responsabilidade civil aos abusos cometidos pela imprensa antes da entrada em vigor do Código Civil de 2002

5.2 A aplicação da responsabilidade civil após a entrada em vigor do Código Civil de 2002 e a introdução do parágrafo único do seu artigo 927

5.3 A técnica da ponderação

6 O IMPACTO DA APLICAÇÃO DAS DIFERENTES MODALIDADES DE RESPONSABILIDADE CIVIL SOBRE A LIBERDADE DE IMPRENSA

6.1 Os fundamentos doutrinários para aplicação da responsabilidade objetiva aos abusos cometidos pela imprensa

6.2 Os fundamentos doutrinários para a continuidade da aplicação da responsabilidade subjetiva aos abusos cometidos pela imprensa.

6.3 A insegurança jurídica gerada pela aplicação da teoria da responsabilidade objetiva

6.4 A aplicação da teoria da responsabilidade subjetiva em detrimento da objetiva e a garantia da adequada responsabilização da imprensa. 


\section{INTRODUÇÃO}

Tanto a responsabilidade civil extracontratual, ou aquiliana ${ }^{1}$, quanto a liberdade de imprensa são institutos consagrados no direito. Seus estudos e seus conceitos passaram por diversas fases ao longo do tempo, sempre refletindo os estágios da sociedade, ora mais libertários, ora mais conservadores.

Desde o seu surgimento, com a Lex Aquilia, no direito romano, a responsabilidade civil aquiliana, ou extracontratual, passou por muitas fases e foi objeto de inúmeras teorias, até que, no século XIX, o Código Civil napoleônico inseriu a culpa como pressuposto da responsabilidade civil, influenciando diferentes legislações, inclusive o Código Civil brasileiro de 1916.

Ao longo do século XX, verificou-se que a responsabilidade civil extracontratual com análise de culpa não mais atendia à realidade trazida pela Revolução Industrial, pela massificação das relações, pela proliferação de eventos danosos e, por fỉm, pela ascensão da dignidade da pessoa humana como princípio norteador dos Estados europeus após a Segunda Guerra Mundial.

Em razão disso, o critério de responsabilização civil baseado na rígida análise da culpa passou a ser amenizado em favor da simples caracterização do dano ligada ao exercício de atividade de risco. Surge a responsabilidade civil objetiva, sem a tradicional análise de culpa.

No Brasil, a par da já existente movimentação doutrinária, jurisprudencial e até mesmo legislativa no sentido da responsabilização civil independentemente da análise da culpa, o Código Civil de 2002 contemplou a responsabilidade civil objetiva em uma cláusula aberta: o parágrafo único do artigo 927, que prevê essa modalidade de responsabilização, além dos casos previstos em lei, quando "a atividade normalmente desenvolvida pelo autor do dano implicar, por sua natureza, riscos para os direitos de outrem".

1 Nesta dissertação, preferiu-se utilizar o termo "responsabilidade civil extracontratual" apenas com o intuito de uniformizar a linguagem. 
E, desde então, tal cláusula vem sendo utilizada em nosso ordenamento jurídico de maneira indiscriminada e sujeita a construção doutrinária e interpretação judicial sobre quais atividades podem implicar danos a outrem.

Por outro lado, a origem da imprensa remonta à Baixa Idade Média, com os tipos móveis de Gutenberg. Porém, foi a partir da Revolução Industrial que os jornais puderam ser considerados veículos de informação de massa.

Já a liberdade de imprensa, tal como a conhecemos na atualidade, foi concebida a partir dos ideais revolucionários que eclodiram na Europa e nas Américas (mais especificamente nos Estados Unidos da América) nos séculos XVIII e XIX, quando a demanda por informações cresceu em razão da vontade declarada da sociedade de fazer parte do processo decisório. Foi nesse momento que a Declaração dos Direitos do Homem e do Cidadão francesa e a Primeira Emenda Constitucional norte-americana fixaram a liberdade de expressão como fundamento da democracia, no que foram seguidas por outras nações.

No Brasil, a liberdade de imprensa teve seu tratamento sempre regulamentado na Constituição Federal. E, desde a primeira Constituição, datada de 1824, até a atual, contemplou-se tal liberdade como regra geral, reprimindo, a posteriori os abusos em nome dela cometidos. Essa regra, no entanto, sofreu limitações na Constituição de 1937, bem como durante o regime militar, quando a imprensa foi submetida à censura.

Destaca-se que foi durante o regime militar que o Brasil conheceu sua Lei de Imprensa. Datada de 1967, a Lei $n^{0}$ 5.250, que Freitas Nobre preferiu denominar Lei Brasileira da Informação ${ }^{2}$, possuía preceitos bastante razoáveis e de relevante importância tanto na regulamentação da atividade da imprensa no país quanto na forma de sua responsabilização por ilícitos cometidos. A Lei de Imprensa vigorou até 2009 (ainda que não em sua totalidade), ano em que o Supremo Tribunal Federal a declarou incompatível com a ordem constitucional vigente, por meio do julgamento da Ação de Descumprimento de Preceito Fundamental no 130.

A partir da contextualização histórica, é possível traçar um paralelo entre a liberdade de imprensa e a responsabilidade civil; verificar a evolução de um e outro

2 NOBRE, Freitas. Comentários à Lei de Imprensa: lei n. 5250, de 09-02-1967. 3. ed. São Paulo: Saraiva.1985. p. 1. Segundo Freitas Nobre, essa seria a denominação correta, uma vez que a lei "considera não apenas os órgãos impressos, mas todos os demais meios de divulgação". 
instituto no Brasil e no âmbito internacional; e analisar os pressupostos jurídicos que os regem, para então concluir qual a modalidade de responsabilização mais adequada para dirimir questões oriundas da imprensa no Brasil.

Após a entrada em vigor do Código Civil de 2002 e a previsão existente em seu artigo 927, parágrafo único, de que as atividades de risco respondem de maneira objetiva pelos riscos causados, passou-se a questionar se a atividade dos órgãos de imprensa se enquadra ou não no conceito de atividade de risco. Vale lembrar que os julgamentos relacionados à atividade exercida pela imprensa se restringiam, em um primeiro momento, aos crimes contra a honra. Em seguida, após a Lei de Imprensa, passou-se a prever de maneira mais assertiva a possibilidade de reparação civil dos abusos cometidos pelos veículos de comunicação contra os direitos da personalidade. Mas somente após a Constituição Federal, promulgada em 1988, o número de ações de natureza civil contra a imprensa aumentou significativamente, possibilitando o desenvolvimento e a evolução da jurisprudência relacionada ao assunto, em razão da positivação dos princípios fixados no artigo $5^{\circ}$, especialmente nos incisos $\mathrm{V}$ e $\mathrm{X}$, que asseguram a ampla indenização e a proteção à intimidade, à vida privada, à honra e à imagem das pessoas.

A partir daquele momento, os conflitos entre os princípios estabelecidos nos dispositivos referidos e aqueles previstos nos incisos IX e XIV, que garantem a liberdade de imprensa, tornaram-se muito frequentes, de modo que doutrina e jurisprudência, antes mesmo da aplicação da responsabilidade civil objetiva, desenvolveram técnicas e conceitos para julgar e analisar tais conflitos na esfera civil.

E isso ocorreu, é de se destacar, em detrimento da Lei de Imprensa, que impunha expressamente a reparação de danos àquele que agisse com dolo ou culpa "no exercício da liberdade de manifestação de pensamento e de informação" (conforme texto do artigo 49 da Lei de Imprensa).

E, ainda que a Lei de Imprensa tenha sido declarada incompatível com a Constituição Federal pelo Supremo Tribunal Federal, por meio do julgamento da Arguição de Descumprimento de Preceito Fundamental (ADPF) n $n^{\circ} 130$, o que aconteceu somente em 2009, o fato é que, muito antes desse marco histórico, aos delitos cometidos pela imprensa no exercício de sua função constitucional, como dito, já se levantava a possibilidade de aplicação da responsabilidade civil objetiva. 
Atualmente, parece haver poucos questionamentos por parte da doutrina e da jurisprudência brasileiras acerca da aplicação da responsabilidade subjetiva aos delitos cometidos pela imprensa. Até porque a simples condenação da imprensa sem a análise de culpa nos parece contraditória em relação à amplitude do princípio da liberdade de expressão e à vedação constitucional à censura.

Nesse sentido é interessante observar que, nos Estados Unidos, país onde as indenizações somam quantias elevadas, incluindo não apenas a reparação integral, mas também a punição exemplar ao agente infrator, a responsabilização da imprensa não atinge tais proporções se não houver prova de que o órgão de comunicação tenha agido com dolo ou, no mínimo, imprudência - o famoso binômio actual malice e reckless disregard, facilmente comparado à noção de culpa no nosso ordenamento.

Se, de um lado, parece ser cada vez mais aceitável a aplicação da responsabilidade objetiva, baseada na teoria do risco da atividade, consagrada na parte final do artigo 927 , parágrafo único, do Código $\mathrm{Civil}^{3}$, por outro lado se questiona se a liberdade de imprensa, tão importante ao exercício da cidadania e à manutenção da democracia, não será tolhida em função dessa ampla modalidade de responsabilização.

Enfim, parece-nos que os estudos em direito pouco se aprofundaram sobre o seguinte questionamento: a atribuição da responsabilidade objetiva aos danos causados pela imprensa não implicaria restrição à liberdade de informar, especialmente nos casos em que ela atua como fiscalizadora dos agentes públicos ${ }^{4}$ ?

3 “[...] a ponderação dará o tom da injustiça do dano causado. Mas, a se determinar, nesse balanceamento, de acordo com os critérios que sejam aplicáveis, e ao que se remete à seara própria, a prevalência, por exemplo, da imagem, honra ou privacidade sobre a informação, não se cogitará de culpa para responsabilizar os órgãos de imprensa. Sua responsabilidade se dá independentemente desse elemento subjetivo. Mas por que fundamento? Com base em quê? No risco especial da atividade e, assim, no parágrafo único do art. 927 do Código Civil de 2002." (GODOY, Cláudio Luiz Bueno de. Responsabilidade civil pelo risco da atividade: uma cláusula geral no Código Civil de 2002. São Paulo: Saraiva, 2009. p. 140).

4 “[...] sempre que se institui a responsabilidade civil objetiva em um setor econômico, os custos operacionais se engrandecem justamente porque se deve contabilizar uma crescente cifra de saques do caixa para cumprir sentenças indenizatórias. Trata-se daí do ônus decorrente do risco de uma atividade perigosa. A imprensa seria injustamente penalizada pela inserção nesse rol, porque não prejudica a sociedade; ao contrário, presta um serviço relevante e significativo [...] Qual o propósito de colocar a imprensa no mesmo patamar dessas atividades? Justamente pela função social da imprensa é que defendo a não-inclusão de suas atividades no art. 927, parágrafo único, do CC.” (ZULIANI, Ênio Santarelli. Responsabilidade civil pelos abusos na Lei de Imprensa. In: SILVA, Regina Beatriz Tavares da; SANTOS, Manoel Joaquim Pereira dos (Coords.). Responsabilidade civil na internet e nos demais meios de comunicação. São Paulo: Saraiva, 2007. p. 381-382). 
Essa indagação encontra ainda mais razão de ser na atual conjuntura evolutiva da responsabilidade civil, que parece privilegiar a prevenção de riscos e danos, por conta do impacto econômico das indenizações.

Portanto, o objetivo da pesquisa é verificar o impacto da aplicação de uma ou outra modalidade de responsabilidade civil extracontratual, atualmente previstas em nosso ordenamento jurídico, às questões relacionadas à imprensa.

Pretende-se analisar os pressupostos da responsabilidade civil por dano cometido pela imprensa, sob o enfoque dos princípios da liberdade de imprensa e do direito à informação, consagrados universalmente como pressupostos da democracia. E, por fim, responder à grande questão já formulada anteriormente sobre a mais adequada modalidade de responsabilização civil da imprensa.

Em outras palavras: a atribuição da responsabilidade objetiva aos danos causados pela imprensa não implicaria restrição à liberdade de informar, especialmente nos casos em que ela atua como fiscalizadora dos agentes públicos? Deve haver diferença na atribuição da responsabilidade civil a ilícitos cometidos contra agentes públicos e àqueles praticados contra pessoas comuns?

Serão os modelos da responsabilidade civil objetiva e da ponderação os mais adequados à solução das controvérsias nas quais se questiona a conduta da imprensa?

Seria adequado que a imprensa fosse julgada sem a análise de sua culpa, em detrimento do interesse público? Será a técnica da ponderação entre os princípios uma construção adequada ao modelo de responsabilidade civil adotado no Brasil? Se utilizada tal técnica, como aplicar os preceitos relacionados à indenização civil?

São, em linhas gerais, essas as questões que a presente dissertação de mestrado busca responder após a análise dos fundamentos e da história dos institutos da responsabilidade civil e da liberdade de expressão, indicando desde já que, diante da experiência profissional da autora, se crê na hipótese de que a responsabilidade civil objetiva prejudica o bom andamento da imprensa, pois impede o pleno exercício da sua liberdade de expressão na medida em que amedronta seus agentes, especialmente quando a responsabilização ultrapassa os limites da mera indenização ou reparação e atinge a esfera da punição. 
E, nesse sentido, parece lógico que a imprensa não pode ser punida por exercer sua atividade de maneira regular sem que se verifique a existência, ao menos, de culpa de sua parte, especialmente porque dentre as funções da imprensa está a de auxiliar na manutenção da democracia por meio da fisscalização do Estado e seus agentes. 


\section{CONCLUSÃo}

Conforme havia sido proposto, foi feita uma análise da evolução da responsabilidade civil extracontratual para o entendimento das diferentes fases e teorias desse importante instituto.

Verificou-se a evolução dos conceitos de culpa, desde a Lei de Talião, inserida no Código de Hamurabi, passando pela Lei das XII Tábuas, a Lei Aquília e as suas evoluções, até chegar ao Código Civil francês, importante marco no direito, e as presunções atribuídas ao conceito culpa, que se mostrava cada vez mais insuficiente e para regular todas as situações surgidas com a evolução da humanidade, especialmente com a Revolução Industrial.

As teorias do risco também foram estudadas nessa dissertação e se verificou o alargamento de sua aplicação e, mais uma vez, as críticas que a elas foram feitas.

Tanto a culpa quanto o risco foram incorporados na legislação brasileira e foi possível entender como a jurisprudência tratou de incentivar a aplicação da teoria da responsabilidade objetiva no país.

A Constituição de 1988 trouxe novos ares à interpretação das leis no Brasil, mas foi o Código Civil de 2002 que alterou substancialmente o cenário da responsabilidade civil extracontratual. Isso porque trouxe entre seus dispositivos uma cláusula geral de responsabilidade objetiva, baseada no risco da atividade. Trata-se do parágrafo único do artigo 927 do Código Civil.

Essa cláusula foi muito criticada e elogiada pelo mesmo motivo, por ser excessivamente ampla. Discutiu-se muito sobre o real significado dela, se se tratava do risco-proveito ou do risco-criado, chegando-se à conclusão de que nenhuma delas se amoldaria perfeitamente à interpretação do Código Civil.

Em seguida, passou-se a estudar a liberdade de imprensa. O conceito de imprensa foi desenvolvido, desde Gutemberg até os dias de hoje em que se convive com grandes meios de comunicação de massa e também com a vasta diversidade encontrada na internet. 
A liberdade de imprensa também foi analisada. Foi possível compreender a cadeia entrelaçada entre liberdade de pensamento, liberdade de informação, liberdade de expressão e finalmente, liberdade de imprensa. Além disso, a dissertação revelou a importância da imprensa para a sociedade e especialmente para a democracia, por meio da contextualização da própria evolução desse conceito, ao longo dos períodos do Renascimento e do Iluminismo.

A dissertação discorreu sobre as declarações de direitos surgidas na França e Estados Unidos, que são a base para o estudo da liberdade de imprensa. Verificou-se como as guerras mundiais influenciaram a liberdade de expressão e fizeram surgir novas declarações em todo o mundo, todas elas enaltecendo a liberdade de expressão.

Após a contextualização da liberdade de imprensa no mundo, foi feita a contextualização no Brasil. Foi possível verificar que a liberdade sempre esteve presente nas constituições do país, mas nem sempre foi respeitada. Já com relação à regulamentação da imprensa, percebeu-se que houve inúmeras normas, muitas vezes causando alguma confusão.

Somente em 1953 foi publicada efetivamente uma lei de imprensa no Brasil. Esta lei inseriu a primeira cláusula de responsabilidade civil pelos abusos de imprensa no país, muito pouco utilizada nos tribunais.

Em 1967, em pleno regime militar, foi promulgada a Lei 5.250, instituindo a Lei de Imprensa no Brasil. Essa lei ficou em vigor até maio de 2009, quando a $\operatorname{ADPF~}^{\circ} 130$, julgou-a incompatível com ordem constitucional vigente. Isso porque a Constituição de 1988, ao garantir o amplo acesso à indenização, o direito de resposta e garantir ampla proteção aos direitos da personalidade, derrogou uma série de dispositivo da Lei de Imprensa.

A seguir, o conhecimento adquirido com os capítulos anteriores se uniu e os estudos sobre a responsabilização da imprensa se iniciaram.

Nesse ponto, se estabeleceu os contornos do potente conflito entre a liberdade de imprensa e a os direitos da personalidade. Foi feito um paralelo entre a evolução da própria imprensa e dos chamados direitos da quarta geração, para demonstrar a importância desse conflito, apresentando, desde já, a formas de resolução, pela técnica da ponderação, da actual malice, do interesse público e do abuso de direito. 
Um corte foi feito para apresentar o histórico de responsabilização civil até a entrada em vigor da Lei 2.883/1953. Ao longo desse período pouco se falou em responsabilização civil da imprensa. Em seguida, o período entre 1953 e 1967 foi analisado. Havia um número maior de julgados, porém, apenas na esfera criminal. A responsabilidade civil da imprensa ainda era pouco aplicada.

A responsabilidade civil da imprensa passou a ser mais aplicada após a entrada em vigor da Lei de Imprensa, mas, ainda assim, muito timidamente. De qualquer forma, a Lei 5.250/1976, apesar de ter sido promulgada durante o regime militar, era bastante avançada e trouxe em sua redação a forma pela qual a imprensa deveria ser responsabilizada, distribuiu a responsabilidade entre os agentes de imprensa, apresentou a tarifação e os parâmetros para as condenações por danos moais e, muito importante, elegeu um único artigo para tratar das excludentes de ilicitude.

A Constituição de 1988 trouxe novos preceitos para o direito brasileiro. Ela ampliou a proteção aos direitos da personalidade e garantiu sua reparação. Com isso, o número de ações civis envolvendo abuso de impressa começou a subir, enquanto que o número de ações criminais diminuiu. Em meados dos anos 2000, institui-se o que costumamos chamar de indústria do dano mora.

Em função dos preceitos existentes na Constituição Federal, a Lei de Imprensa passou a ter alguns de seus dispositivos ignorados pela jurisprudência. Foram deixando de ser aplicados os artigos que instituíam a tarifação das indenizações, os artigos relacionados ao rito especial da Lei de Imprensa, dentre outros.

O fim da Lei de Imprensa foi decretado com o julgamento da ADPF $n^{\circ}$ 130, cujo julgamento foi abordado nessa dissertação.

A partir daí, já com farto material jurisprudencial, buscou-se avaliar como ocorreu a responsabilização da imprensa no Brasil após a Constituição Federal de 1988, tendo em vista uma maior valoração dos direitos da personalidade, aliado à facilidade com que as informações se propagam na era digital.

Uma pausa na análise da situação nacional foi feita, para se verificar a forma como ocorre a responsabilização civil da imprensa nos Estados Unidos. Foi feita uma abordagem 
sobre a doutrina da actual malice e do reckless disregard, como foi instituída e como está sendo a aplicação atual.

Voltando à análise nacional. Foi feita uma divisão temporal para entender como a responsabilidade civil pelos abusos de imprensa evoluiu até a Constituição, após a Constituição e antes da entrada em vigor do Código Civil de 2002 e após esta data até os dias atuais.

Apurou-se que antes da entrada em vigor do Código Civil de 2002 e do estabelecimento da cláusula geral de responsabilidade objetiva pelo risco da atividade, houve ao menos uma decisão fundada na responsabilidade objetiva, as demais decisões inicialmente invocavam a Lei de Imprensa e aos poucos passaram a ser proferidas com fundamento no Código Civil.

Após a entrada em vigor do atual Código Civil, várias decisões foram proferidas com fundamento na modalidade objetiva da responsabilidade civil. Tais decisões foram analisadas e, ao final, também foi feita uma verificação sobre a técnica da ponderação e o teste de razoabilidade.

Verificou-se que houve intensa discussão doutrinária sobre a aplicabilidade das modalidades subjetiva e objetiva de responsabilidade civil aos abusos da imprensa, o que foi retratado na dissertação, contando com a opinião da autora.

Por fim, foi feito um balanço das decisões analisadas para aferir qual das modalidades de responsabilidade civil seria a mais adequada para aplicação aos abusos dos meios de comunicação. Verificou-se que a aplicação da responsabilidade civil objetiva pode ter impacto negativo sobre a liberdade de imprensa, porque a) limita o exercício da liberdade de manifestação do pensamento; b) não faz com que os veículos de comunicação sejam mais cautelosos na apuração e divulgação de suas matérias, pelo contrário, já que não haverá diferença entre a conduta diligente e a conduta displicente; e, c) não amplia e nem altera a efetividade da responsabilização da imprensa por seus deslizes, ou seja, os abusos de imprensa não deixarão de ser reprimidos e a liberdade de manifestação do pensamento não será enfraquecida, até porque:

A proteção mais rigorosa da liberdade de expressão não protegeria um homem que gritasse, falsamente, fogo em um teatro causando pânico. juiz Oliver Wendell Holmes Schenck versus Estados Unidos, 1919 


\section{REFERÊNCIAS}

ALEXY, Robert. Teoria dos direitos fundamentais. Tradução de Virgílio Afonso da Silva. 2. ed. São Paulo: Malheiros, 2011.

AZEVEDO, Álvaro Villaça. Teoria geral das obrigações e responsabilidade civil. 12. ed. São Paulo: Atlas, 2011.

BARROSO, Luis Roberto. Colisão entre liberdade de expressão e direitos da personalidade. Critérios de ponderação. Interpretação adequada do Código Civil e da Lei de Imprensa. Disponível em: $<$ http://www.migalhas.com.br/arquivo_artigo/art_03-1001.htm>. Acesso em: 29 jun. 2018.

BDINE JÚNIOR, Hamid Charaf. Responsabilidade civil dos veículos de comunicação por atos próprios. In: SILVA, Regina Beatriz Tavares da; SANTOS, Manoel J. Pereira dos (Coords.). Responsabilidade civil na internet e nos demais meios de comunicação. São Paulo: FGV; Saraiva, 2007. p. 415-443.

BEVILAQUA, CLOVIS. Theoria geral do direito civil. 6. ed. atualizada por Achilles Bevilaqua. Rio de Janeiro: Paulo de Azevedo, 1953.

BITTAR, Carlos Alberto. Os direitos da personalidade. 8. ed. Rev., aum. e mod. por Eduardo C. B. Bittar. São Paulo: Saraiva, 2015.

BITTAR, Carlos Alberto. Responsabilidade civil nas atividades nucleares. São Paulo: Revista dos Tribunais, 1982.

BOBBIO, Norberto. A era dos direitos. Tradução de Carlos Nelson de Souza. Rio de Janeiro: Elsevier, 2004.

BONAVIDES, Paulo. Curso de direito constitucional. 5. ed. São Paulo: Malheiros, 1994.

BRASIL, Superior Tribunal de Justiça. Súmula 281. Disponível em:

$<$ https://ww2.stj.jus.br/docs_internet/revista/eletronica/stj-revista-sumulas-

2011_21_capSumula281.pdf $>$. Acesso em: 4 jun. 2018.

BRASIL. Constituição da República dos Estados Unidos do Brasil, de 24 de fevereiro de 1891. Rio de Janeiro, 24 fev. 1891. Disponível em:

$<$ http://www.planalto.gov.br/ccivil_03/Constituicao/Constituicao91.htm>. Acesso em: 11 nov. 2016.

BRASIL. Constituição dos Estados Unidos do Brasil, de 18 de setembro de 1946. Rio de Janeiro, 18 set. 1946. Disponível em:

$<$ https://www.planalto.gov.br/ccivil_03/Constituicao/Constituicao46.htm>. Acesso em: 14 nov. 2016.

BRASIL. Decreto 38.888 de 22 de novembro de 1823. Manda executar provisoriamente o projecto de lei da Assembléa Constituinte sobre liberdade de imprensa. Rio de Janeiro, 
22 nov. 1823. Disponível em:

$\leq$ http://www.planalto.gov.br/ccivil_03/decreto/historicos/dim/DIM-22-11-1823.htm->.

Acesso em 11 nov. 2016.

BRASIL. Decreto de 2 de março de 1821. Sobre a liberdade da imprensa. Rio de Janeiro, 2 mar. 1821. Disponível em:

$<$ http://www.planalto.gov.br/ccivil_03/decreto/historicos/dim/DIM-2-3-1821.htm>.

Acesso em: 11 nov. 2016.

BRASIL. Decreto no 4.269, de 17 de janeiro de 1921. Regula a Repressão do Anarchismo. Rio de Janeiro, 17 jan. 1921. Disponível em:

$<$ http://www2.camara.leg.br/legin/fed/decret/1920-1929/decreto-4269-17-janeiro-1921-

776402-publicacaooriginal-140313-pl.html>. Acesso em: 11 nov. 2016.

BRASIL. Decreto $n^{0}$ 4.743, de 31 de outubro de 1923. Regula a liberdade de imprensa e dá outras providencias. Rio de Janeiro, 31 out. 1923. Disponível em:

$<$ http://www2.camara.leg.br/legin/fed/decret/1920-1929/decreto-4743-31-outubro-1923567758-publicacaooriginal-91090-pl.html>. Acesso em: 14 nov. 2016.

BRASIL. Decreto no 847, Promulga o Código Penal. 11 out. 1890. Disponível em: $<$ http://legis.senado.gov.br/legislacao/ListaPublicacoes.action?id=66049>. Acesso em: 11 nov. 2016.

BRASIL. Decreto-Lei no 1.949, de 30 de dezembro de 1939. Dispõe sobre o exercício de atividades de imprensa e propaganda no território nacional e dá outras providências. Rio de Janeiro, 30 dez. 1939. Disponível em: <http://www.planalto.gov.br/ccivil_03/decretolei/1937-1946/Del1949.htm>. Acesso em: 14 nov. 2016.

BRASIL. Lei 37.987 de 20 de setembro de 1830. Sobre o abuso da liberdade da imprensa. Rio de Janeiro, 28 set. 1830. Disponível em:

$<$ http://www2.camara.leg.br/legin/fed/lei_sn/1824-1899/lei-37987-20-setembro-1830565654-publicacaooriginal-89402-pl.html $>$. Acesso em: 11 nov. 2016.

BRASIL. Lei de 16 de setembro de 1830. Manda executar o Codigo Criminal. Rio de Janeiro, 8 jan. 1831. Disponível em: $<$ http://www.planalto.gov.br/ccivil_03/leis/lim/LIM16-12-1830.htm>. Acesso em: 11 nov. 2016.

BRASIL. Presidência da República. Decreto-Lei no 510, de 20 de março de 1969. Altera dispositivos do Decreto-lei no 314, de 13 de março de 1967, e dá outras providências. Brasília, 20 mar. 1969. Disponível em: <http://www.planalto.gov.br/ccivil_03/decretolei/1965-1988/Del0510.htm>. Acesso em: 19 abr. 2018.

BRASIL. Presidência da República. Lei 1.208 de 5 de janeiro de 1953. Define os crimes contra o Estado e a Ordem Política e Social, e dá outras providências. Rio de Janeiro, 5 jan. 1953. Disponível em: <http://www2.camara.leg.br/legin/fed/lei/1950-1959/lei-1802-5janeiro-1953-367324-norma-pl.html>. Acesso em: 18 abr. 2018.

BRASIL. Presidência da República. Lei 5.250 de 9 de fevereiro de 1967. Regula a liberdade de manifestação de pensamento e de informação. Brasília, 9 fev. 1967. 
Disponível em: <http:/www2.camara.leg.br/legin/fed/lei/1960-1969/lei-5250-9-fevereiro1967-359026-normaatualizada-pl.html>. Acesso em: 15 abr. 2017.

BRASIL. Presidência da República. Lei no 2.083 de 12 de novembro de 1953. Regula a Liberdade de Imprensa. Rio de Janeiro, 12 nov. 1953. Disponível em:

$<$ http://www.planalto.gov.br/ccivil_03/leis/L2083.htm>. Acesso em 30 abr. 2017.

BRASIL. Presidência da República. Lei no 4.117, de 27 de agosto de 1962. Institui o Código Brasileiro de Telecomunicações. Brasília, 14 dez. 1962. Disponível em: $<$ http://www.planalto.gov.br/ccivil_03/leis/L4117.htm>. Acesso em: 15 abr. 2017.

BRASIL. Superior Tribunal de Justiça. Agravo de Instrumento no 387.521/MG. Relator: ministro Carlos Alberto Menezes Direito. Brasília, 24 ago. 2001. Disponível em: $<$ https://ww2.stj.jus.br/processo/revista/documento/mediado/?componente=MON\&sequen cial $=109206 \&$ num_registro $=200100582380 \&$ data $=20010824>$. Acesso em: 25 maio 2018.

BRASIL. Superior Tribunal de Justiça. Agravo em Recurso Especial n 1.076.309/SP. Relatora: ministra Isabel Gallotti. Brasília, 15 ago 2017. Disponível em:

$<$ https://ww2.stj.jus.br/processo/revista/documento/mediado/?componente=MON\&sequen cial $=74963181 \&$ num_registro $=201700683074 \&$ data $=20170822 \&$ formato $=P D F>$. Acesso em: 9 jul. 2018.

BRASIL. Superior Tribunal de Justiça. Agravo Interno no Agravo em Recurso Especial $\mathbf{n}^{\mathbf{0}}$ 1.297.567-RJ. Terceira Turma. Brasília, 23 abr. 2013. Disponível em:

$<$ https://ww2.stj.jus.br/processo/revista/documento/mediado/?componente=ITA\&sequenci $\mathrm{al}=1229339 \&$ num_registro $=201102621882 \& \mathrm{data}=20130502 \&$ formato $=\mathrm{PDF}>$. Acesso em: 8 jul. 2018.

BRASIL. Superior Tribunal de Justiça. Agravo Interno no Agravo em Recurso Especial n 885.598/RJ. Relator: ministro Marco Aurélio Bellizze. Brasília, 17 maio 2017.

Disponível em:

$<$ https://ww2.stj.jus.br/processo/revista/documento/mediado/?componente=MON\&sequen cial $=72553092 \&$ num_registro $=201600704940 \&$ data $=20170824 \&$ formato $=P D F>$. Acesso em: 8 jul. 2018.

BRASIL. Superior Tribunal de Justiça. Recurso Especial $\mathbf{n}^{\mathbf{0}}$ 11.884-0/SP. $4^{\mathrm{a}}$ Turma. Brasília, 16 nov. 1993. Disponível em:

$<$ https://ww2.stj.jus.br/processo/ita/documento/mediado/?num_registro=199100119520\&d t_publicacao $=01-08-1994 \&$ cod_tipo_documento $=>$. Acesso em: 25 maio 2018

BRASIL. Superior Tribunal de Justiça. Recurso Especial no 85.019/RJ. $4^{\mathrm{a}}$ Turma. Brasília, 10 mar. 1998. Disponível em:

$<$ https://ww2.stj.jus.br/processo/ita/documento/mediado/?num_registro=199600007268\&d t_publicacao=18-12-1998\&cod_tipo_documento=>. Acesso em: 11 jun. 2018

BRASIL. Superior Tribunal de Justiça. Recurso Especial n⿳0 109.470/PR. Terceira Turma. Brasília, 15 dez. 1997. Disponível em:

$<$ https://ww2.stj.jus.br/processo/ita/documento/mediado/?num_registro=199600618623\&d t_publicacao=21-06-1999\&cod_tipo_documento=>. Acesso em: 11 jun. 2018. 
BRASIL. Superior Tribunal de Justiça. Recurso Especial no 120.615/RS. $4^{\text {a }}$ Turma. Brasília, 25 out 1999. Disponível em:

$<$ https://ww2.stj.jus.br/processo/ita/documento/mediado/?num_registro=199700123120\&d t_publicacao=27-03-2000\&cod_tipo_documento=>. Acesso em: 25 maio 2018.

BRASIL. Superior Tribunal de Justiça. Recurso Especial n⿳0 123.205/ES. $4^{\text {a }}$ Turma. Brasília, 25 nov. 1997. Disponível em:

$<$ https://ww2.stj.jus.br/processo/ita/documento/mediado/?num_registro=199700175383\&d t_publicacao=16-02-1998\&cod_tipo_documento=>. Acesso em: 25 maio 2018.

BRASIL. Superior Tribunal de Justiça. Recurso Especial no 127.631/RS. $3^{\text {a }}$ Turma. Brasília, 10 nov. 1997. Disponível em:

$<$ https://ww2.stj.jus.br/processo/ita/documento/mediado/?num_registro=199700256278\&d t_publicacao=15-12-1997\&cod_tipo_documento=>. Acesso em: 25 maio 2018.

BRASIL. Superior Tribunal de Justiça. Recurso Especial no ${ }^{\mathbf{1}}$ 128.318/RJ. $4^{\text {a }}$ Turma. Brasília, 22 set. 1997. Disponível em:

$<$ https://ww2.stj.jus.br/processo/ita/documento/mediado/?num_registro=199700268349\&d t_publicacao=09-12-1997\&cod_tipo_documento=>. Acesso em: 25 maio 2018.

BRASIL. Superior Tribunal de Justiça. Recurso Especial no 141.638/RJ. 4 $4^{\mathrm{a}}$ Turma. Brasília, 25 nov. 1997. Disponível em:

$<$ http://www.stj.jus.br/SCON/jurisprudencia/doc.jsp?processo=141638\&b=ACOR\&p=true

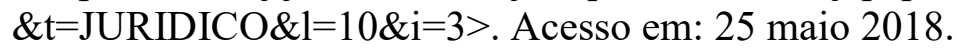

BRASIL. Superior Tribunal de Justiça. Recurso Especial no 167.490/SP. $4^{\text {a }}$ Turma. Brasília, 13 jun. 2000. Disponível em:

https://ww2.stj.jus.br/processo/ita/documento/mediado/?num_registro=199800185925\&dt publicacao=18-09-2000\&cod_tipo_documento=>. Acesso em: 25 maio 2018.

BRASIL. Superior Tribunal de Justiça. Recurso Especial no 179.815/RJ. $3^{\text {a }}$ Turma. Brasília, 5 out. 1999. Disponível em:

$<$ https://ww2.stj.jus.br/processo/ita/documento/mediado/?num_registro=199800474803\&d t_publicacao=13-12-1999\&cod_tipo_documento=>. Acesso em: 25 maio 2018.

BRASIL. Superior Tribunal de Justiça. Recurso Especial no 192.786/RS. Terceira Turma. Brasília, 23 nov. 1999. Disponível em:

https://ww2.stj.jus.br/processo/ita/documento/mediado/?num_registro=199800783890\&dt publicacao $=27-03-2000 \&$ cod_tipo_documento=>. Acesso em: 11 jun. 2018.

BRASIL. Superior Tribunal de Justiça. Recurso Especial no 219.291/RS. $3^{\text {a }}$ Turma. Brasília, 9 maio 2000. Disponível em:

https://ww2.stj.jus.br/processo/ita/documento/mediado/?num_registro=199900528522\&dt publicacao $=01-08-2000 \&$ cod_tipo_documento $=>$. Acesso em: 25 maio 2018.

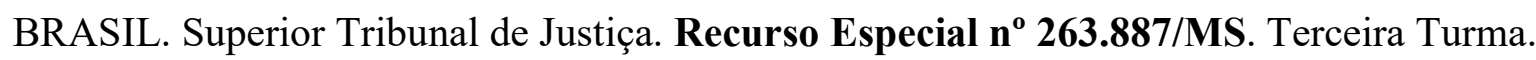
Brasília, 15 mar. 2001. Acesso em:

$<$ https://ww2.stj.jus.br/processo/revista/documento/mediado/?componente=IMG\&sequenci $\mathrm{al}=57511 \&$ num_registro $=200000610747 \& \mathrm{data}=20010507 \&$ formato $=\mathrm{PDF}>$. Acesso em: 8 jun. 2018. 
BRASIL. Superior Tribunal de Justiça. Recurso Especial n 264.515/RJ. Quarta Turma. Brasília, 13 set. 2000. Disponível em:

$<$ https://ww2.stj.jus.br/processo/revista/documento/mediado/?componente=IMG\&sequenci al $=73093 \&$ num_registro $=200000626279 \&$ data $=20001016 \&$ formato $=P D F>$. Acesso em: 11 jun. 2018.

BRASIL. Superior Tribunal de Justiça. Recurso Especial no 299.846/MG. Terceira Turma. Brasília, 25 set. 2001. Disponível em:

$<$ https://ww2.stj.jus.br/processo/revista/documento/mediado/?componente=IMG\&sequenci al $=34212 \&$ num_registro $=200100042708 \& d a t a=20020204 \&$ formato $=P D F>$. Acesso em: 11 jun. 2018.

BRASIL. Superior Tribunal de Justiça. Recurso Especial no 331.182/SE. Quarta Turma. Brasília, 3 set. 2002. Disponível em:

$<$ https://ww2.stj.jus.br/processo/revista/documento/mediado/?componente=ITA\&sequenci $\mathrm{al}=370588 \&$ num_registro $=200100921156 \&$ data $=20030317 \&$ formato $=P D F>$. Acesso em: 8 jun. 2018.

BRASIL. Superior Tribunal de Justiça. Recurso Especial no 35.790/SP. $3^{\text {a }}$ Turma. Brasília, 14 mar. 1994. Disponível em:

$<$ https://ww2.stj.jus.br/processo/ita/documento/mediado/?num_registro=199300161628\&d t_publicacao=09-05-1994\&cod_tipo_documento=>. Acesso em: 25 maio 2018.

BRASIL. Superior Tribunal de Justiça. Recurso Especial no 351.779/SP. Terceira Turma. Brasília, 19 nov. 2002. Disponível em:

$<$ https://ww2.stj.jus.br/processo/revista/documento/mediado/?componente=ITA\&sequenci $\mathrm{al}=369941 \&$ num_registro $=200101127779 \&$ data $=20040209 \&$ formato $=\mathrm{PDF}>$. Acesso em: 8 jul. 2018.

BRASIL. Superior Tribunal de Justiça. Recurso Especial no 36.493/SP. Quarta Turma, Brasília, 9 out. 1995. Disponível em:

$<$ https://ww2.stj.jus.br/processo/ita/documento/mediado/?num_registro=199300182439\&d t_publicacao=18-12-1995\&cod_tipo_documento=>. Acesso em: 11 jun. 2018.

BRASIL. Superior Tribunal de Justiça. Recurso Especial no 39.886/SP. $4^{\text {a }}$ Turma.

Brasília, 22 set. 1999. Disponível em:

$<$ https://ww2.stj.jus.br/processo/ita/documento/mediado/?num_registro=199300292196\&d t_publicacao=03-11-1997\&cod_tipo_documento=>. Acesso em: 25 maio 2018.

BRASIL. Superior Tribunal de Justiça. Recurso Especial n 453.598/MT. Quarta Turma. Brasília, 28 out. 2003. Disponível em:

$<$ https://ww2.stj.jus.br/processo/revista/documento/mediado/?componente=ITA\&sequenci $\mathrm{al}=437520 \&$ num_registro $=200200974162 \&$ data $=20031219 \&$ formato $=\mathrm{PDF}>$. Acesso em: 11 jun. 2018.

BRASIL. Superior Tribunal de Justiça. Recurso Especial n 459.857/SP. Quarta Turma, Brasília, 19 nov. 2002. Disponível em:

$<$ https://ww2.stj.jus.br/processo/revista/documento/mediado/?componente=ITA\&sequenci 
$\mathrm{al}=384242 \&$ num_registro $=200201028244 \&$ data $=20030317 \&$ formato $=P D F>$. Acesso em: 6 jun. 2018.

BRASIL. Superior Tribunal de Justiça. Recurso Especial no 52.842/RJ. $3^{\text {a }}$ Turma. Brasília, 16 set. 1997. Disponível em: https://ww2.stj.jus.br/processo/ita/documento/?num_registro=199400252056\&dt_publicac $\mathrm{ao}=27 / 10 / 1997 \&$ cod_tipo_documento $=>$. Acesso em: 25 maio 2018.

BRASIL. Superior Tribunal de Justiça. Recurso Especial $\mathbf{n}^{\mathbf{0}}$ 53.321/RJ. $3^{\text {a }}$ Turma. Brasília, 16 set. 1997. Disponível em:

https://ww2.stj.jus.br/processo/ita/documento/mediado/?num_registro=199400265239\&dt publicacao $=24-11-1997 \&$ cod_tipo_documento $=>$. Acesso em: 25 maio 2018.

BRASIL. Superior Tribunal de Justiça. Recurso Especial no 61.922/RS. $3^{\text {a }}$ Turma. Brasília, 10 nov. 1997. Disponível em:

$<$ https://ww2.stj.jus.br/processo/ita/documento/mediado/?num_registro=199500109425\&d t_publicacao=16-03-1998\&cod_tipo_documento=>. Acesso em: 25 maio 2018.

BRASIL. Superior Tribunal de Justiça. Recurso Especial $\mathbf{n}^{\mathbf{0}} \mathbf{7 2 . 4 1 5 / R J . ~} 3^{\text {a }}$ Turma. Brasília, 14 abr. 1998. Disponível em:

$<$ https://ww2.stj.jus.br/processo/ita/documento/mediado/?num_registro=199500421577\&d t_publicacao $=31-08-1998 \&$ cod_tipo_documento $=>$. Acesso em: 25 maio 2018.

BRASIL. Superior Tribunal de Justiça. Recurso Especial $\mathbf{n}^{\mathbf{0}} \mathbf{7 6 . 7 1 8} / \mathbf{R S}$. Terceira Turma. Brasília, 10 nov. 1997. Disponível em:

$<$ https://ww2.stj.jus.br/processo/ita/documento/mediado/?num_registro=199500525860\&d t_publicacao=15-12-1997\&cod_tipo_documento=>. Acesso em: 6 jun. 2018.

BRASIL. Superior Tribunal de Justiça. Recurso Especial no 828.107/SP. Terceira Turma. Brasília, 12 set. 2006. Disponível em:

$<$ https://ww2.stj.jus.br/processo/revista/documento/mediado/?componente=ITA\&sequenci $\mathrm{al}=646366 \&$ num_registro $=200600691181 \&$ data $=20060925 \&$ formato $=P D F>$. Acesso em: 8 jul. 2018.

BRASIL. Superior Tribunal de Justiça. Recurso Especial $\mathbf{n}^{0}$ 984.803/ES. Terceira Turma. Brasília, 19 ago. 2009. Disponível em:

>https://ww2.stj.jus.br/processo/revista/documento/mediado/?componente=ITA\&sequenci $\mathrm{al}=886843 \&$ num_registro $=200702099361 \&$ data $=20090819 \&$ formato $=P D F>$. Acesso em: 8 jul. 2018.

BRASIL. Superior Tribunal de Justiça. Súmula 221. São civilmente responsáveis pelo ressarcimento de dano, decorrente de publicação pela imprensa, tanto o autor do escrito quanto o proprietário do veículo de divulgação. Data da publicação no DJ: 26/05/1999.

BRASIL. Supremo Tribunal Federal. Agravo de Instrumento $\mathbf{n}^{0}$ 19.635. Primeira Turma. Brasília, 3 jul. 1958. Disponível em:

$<$ http://redir.stf.jus.br/paginadorpub/paginador.jsp?docTP=AC\&docID=6601 $>$. Acesso em: 27 dez. 2017. 
BRASIL. Supremo Tribunal Federal. Arguição de Descumprimento de Preceito Fundamental $\mathbf{n}^{\mathbf{0}}$ 130-7. Tribunal Pleno. Brasília, 30 abr. 2009. Disponível em: $<$ http://redir.stf.jus.br/paginadorpub/paginador.jsp?docTP=AC\&docID $=605411>$. Acesso em: 6 jan. 2017.

BRASIL. Supremo Tribunal Federal. Arguição de Descumprimento de Preceito Fundamental $\mathbf{n}^{\mathbf{0}}$ 130. Tribunal Pleno. Brasília, 30 abr. 2009. Disponível em: $<$ http://redir.stf.jus.br/paginadorpub/paginador.jsp?docTP=AC\&docID=605411 $>$. Acesso em: 30 maio 2018.

BRASIL. Supremo Tribunal Federal. Conflito de Jurisdição n ${ }^{\circ}$ 5.142. Segunda Turma. Brasília, 13 out. 1969. Disponível em:

$<$ http://redir.stf.jus.br/paginadorpub/paginador.jsp?docTP=AC\&docID=28923 $>$. Acesso em: 24 abr. 2018.

BRASIL. Supremo Tribunal Federal. Habeas Corpus n 40.047. Tribunal Pleno. Brasília, 31 jul. 1963. Disponível em:

$<$ http://redir.stf.jus.br/paginadorpub/paginador.jsp?docTP=AC\&docID=57122>. Acesso em: 18 abr. 2018.

BRASIL. Supremo Tribunal Federal. Habeas Corpus no 40976. Tribunal Pleno. Brasília, 23 set. 1964. Disponível em:

$<$ http://redir.stf.jus.br/paginadorpub/paginador.jsp?docTP=AC\&docID=57758 $>$. Acesso em: 18 abr. 2018.

BRASIL. Supremo Tribunal Federal. Recurso Criminal no 1.021. Tribunal Pleno. Brasília, 4 out. 1957. Disponível em:

$<$ http://redir.stf.jus.br/paginadorpub/paginador.jsp?docTP=AC\&docID=262813>. Acesso em: 18 abr. 2018.

BRASIL. Supremo Tribunal Federal. Recurso Criminal no 1.032. Tribunal Pleno. Brasília, 16 set. 1959. Disponível em:

$<$ http://redir.stf.jus.br/paginadorpub/paginador.jsp?docTP=AC\&docID=31195>. Acesso em: 27 dez. 2017.

BRASIL. Supremo Tribunal Federal. Recurso Extraordinário Criminal no $\mathbf{n}^{\mathbf{1}}$ (1.809. Primeira Turma. Brasília, 24 jun. 1947.

BRASIL. Supremo Tribunal Federal. Recurso Extraordinário n⿳0 113.283. Segunda Turma. Brasília, 15 maio 1987. Disponível em:

$<$ http://redir.stf.jus.br/paginadorpub/paginador.jsp?docTP=AC\&docID=203839>. Acesso em: 18 abr. 2018.

BRASIL. Supremo Tribunal Federal. Recurso Extraordinário no 356756/RJ. Relator: ministro Carlos Britto. Brasília, 18 dez. 2009. Disponível em:

$<$ http://stf.jus.br/portal/jurisprudencia/visualizarEmenta.asp?s $1=000080574 \&$ base $=$ baseMo nocraticas $>$. Acesso em: 9 jul. 2018.

BRASIL. Supremo Tribunal Federal. Recurso Extraordinário nº 63.493. RT 403/434. 
BRASIL. Supremo Tribunal Federal. Recurso Extraordinário no 78.789. Primeira Turma. Brasília, 23 maio 1975. Disponível em:

$<$ http://redir.stf.jus.br/paginadorpub/paginador.jsp?docTP=AC\&docID $=174191>$. Acesso em: 18 abr. 2018.

BRASIL. Tribunal de Justiça de São Paulo. Apelação Cível n 094.296-4/7. Primeira Câmara de Direito Privado. São Paulo, 4 abr. 2000. Disponível em:

$<$ https://esaj.tjsp.jus.br/cjsg/getArquivo.do? conversationId=\&cdAcordao=1398989\&cdFor $\mathrm{o}=0 \&$ uuidCaptcha=sajcaptcha_de59eaa0b2a24d839407b53325775de7\&vlCaptcha=erxwk \&novoVlCaptcha=>. Acesso em: 6 jun. 2018.

BRASIL. Tribunal de Justiça de São Paulo. Apelação Cível n 80.346-4/9. Primeira Câmara de Direito Privado do Tribunal de Justiça de São Paulo. Trecho do voto do Desembargador Relator Guimarães e Souza. São Paulo. Data de julgamento: 31/08/1999.

BRASIL. Tribunal de Justiça de São Paulo. Apelação no 1000067-45.2014.8.26.0587.

Segunda Câmara de Direito Privado. São Paulo, 6 jun. 2016. Disponível em:

$<$ https://esaj.tjsp.jus.br/cjsg/getArquivo.do?cdAcordao=9490916\&cdForo=0 $>$. Acesso em: 8 jul. 2018.

BRASIL. Tribunal de Justiça de São Paulo. Apelação no 348.681-4/0-00. Sexta Câmara de Direito Privado. São Paulo, 11 ago. 2005. Disponível em:

$<$ https://esaj.tjsp.jus.br/cjsg/getArquivo.do?cdAcordao $=2032511 \&$ cdForo=0 $>$. Acesso em: 8 jul. 2018.

BRASIL. Tribunal de Justiça de São Paulo. Apelação no 348.681-4/0-00. Sexta Câmara de Direito Privado. São Paulo, 6 set. 2005. Disponível em:

$<$ https://esaj.tjsp.jus.br/cjsg/getArquivo.do? conversationId=\&cdAcordao=1799121\&cdFor $\mathrm{o}=0$ \&uuidCaptcha=sajcaptcha_9f6aae9e34f449a79eb6ebf7300b75af\&vlCaptcha=kaz\&nov oVlCaptcha $=>$. Acesso em: 8 jul. 2018.

CARVALHO, Luiz Gustavo Grandinetti Castanho de. Liberdade de informação e o direito difuso à informação verdadeira. Rio de Janeiro: Renovar, 2003.

CHINELLATO, Silmara Juny de Abreu. Biografias não autorizadas: liberdade de expressão, outros direitos da personalidade e direito de autor. Revista Jurídica LusoBrasileira Lisboa, v. 1, n. 1, p. 205-238, 2015. Disponível em:

$<\mathrm{http}: / /$ cidp.pt/publicacoes/revistas/rjlb/2015/1/2015_01_0205_0238.pdf $>$. Acesso em: 18 mar. 2018.

CHINELLATO, Silmara Juny de Abreu. Direitos da personalidade: o art. 20 do Código Civil e a biografia de pessoas notórias. In: CASSETTARI, Christiano. 10 anos de vigência do Código Civil brasileiro de 2002: estudos em homenagem ao professor Carlos Alberto Dabus Maluf. São Paulo: Saraiva, 2013. p. 126-151.

CORREIA, Atalá. O risco na responsabilidade civil. In: RODRIGUES JÚNIOR, Otavio Luiz; MAMEDE, Gladston; ROCHA, Maria Vital da (Coords.). Responsabilidade Civil Contemporânea. São Paulo: Atlas, 2011. p. 87-95. 
CRETELLA JÚNIOR, José. Comentários à Constituição brasileira de 1988. Rio de Janeiro: Forense Universitária, 1997. v. 1.

CRETELLA JÚNIOR, José. Curso de direito romano: o direito romano e o direito civil brasileiro no Novo Código Civil. 30. ed. Rio de Janeiro: Forense, 2007.

CRUZ, Marco Aurélio Rodrigues da Cunha e. A evolução conceitual da liberdade de expressão na jurisprudência do Supremo Tribunal Federal. Espaço Jurídico: Journal of Law, v.11, n. 2, p. 402-421, 1 May 2011.

D'ELBOUX, Sonia Maria. A liberdade de imprensa e os direitos da personalidade: tensões e limites. 2005. 240 p. Tese (Doutorado em Comunicação e Semiótica) Departamento de Comunicação, Pontifícia Universidade Católica de São Paulo, São Paulo, 2005.

DIAS, José de Aguiar. Da responsabilidade civil. 10. ed. 3. tir. rev. e aum. Rio de Janeiro: Forense, 1997. v. 1.

DOTTI, René Ariel. Proteção da vida privada e liberdade de informação: possibilidade e limites. São Paulo: Revista dos Tribunais, 1980.

FERREIRA, Aluizio. Direito à informação, direito à comunicação: direitos fundamentais na Constituição brasileira. São Paulo: Celso Bastos Editor; Instituto Brasileiro de Direito Constitucional, 1997.

FRANÇA. Declaração dos Direitos do Homem e do Cidadão. Disponível em: $<$ http://www.direitoshumanos.usp.br/index.php/Documentos-anteriores-à-criação-daSociedade-das-Nações-até-1919/declaracao-de-direitos-do-homem-e-do-cidadao1789.html>. Acesso em: 30 mar. 2017.

FRANÇA, Rodrigo Dumans. A teoria do risco aplicada à responsabilidade objetiva. 2009. Dissertação (Mestrado em Direito) - Faculdade de Direito, Universidade de São Paulo, São Paulo, 2009.

GABURRI, Fernando. Da insuficiência da noção de culpa e de risco: da necessidade de um sistema geral objetivo de imputação de responsabilidade civil extracontratual. In: HIRONAKA, Giselda Maria Fernandes Novaes; FALAVIGNA, Maria Clara Osuna Dias (Coords.). Ensaios sobre responsabilidade civil na pós-modernidade. Porto Alegre: Magister, 2007. p. 75-97.

GADELHO JUNIOR, Marcos Duque. Liberdade de informação jornalística e o papel circundante do Estado. 2014. 168 f. Dissertação (Mestrado em Direito) - Faculdade de Direito, Universidade de São Paulo, São Paulo, 2014.

GARCIA, Enéas Costa. Responsabilidade civil dos meios de comunicação. São Paulo: Juarez de Oliveira, 2002.

GODOY, Cláudio Luiz Bueno de. A liberdade de imprensa e os direitos da personalidade. 2. ed. São Paulo: Atlas, 2008. 
GODOY, Cláudio Luiz Bueno de. Responsabilidade civil pelo risco da atividade: uma cláusula geral no Código Civil de 2002. São Paulo: Saraiva, 2009.

GORZONI, Paula. Entre o princípio e a regra: teoria dos direitos fundamentais. Novos Estudos - Cebrap, n.85, p. 273-279, 2009. Disponível em:

$<$ http://www.scielo.br/pdf/nec/n85/n85a13.pdf >. Acesso em: 3 jul. 2018.

HIRONAKA, Giselda Maria Fernandes Novaes. Responsabilidade civil pressuposta: evolução de fundamentos e de paradigmas da responsabilidade civil na contemporaneidade. In: TEPEDINO, Gustavo; FACHIN, Luiz Edson (Coords.). O direito e o tempo: embates jurídicos e utopias contemporâneas - estudos em homenagem ao professor Ricardo Pereira de Lira. Rio de Janeiro: Renovar, 2008. P. 797-825

HIRONAKA, Giselda Maria Fernandes Novaes. Responsabilidade pressuposta: evolução de fundamentos e de paradigmas da responsabilidade civil na contemporaneidade. In: RODRIGUES JÚNIOR, Otavio Luiz; MAMEDE, Gladston; ROCHA, Maria Vital da (Coords.). Responsabilidade civil contemporânea. São Paulo: Atlas, 2011. p. 40-60.

ILDEFONSO, Carlos Brandão. Responsabilidade objetiva: verdade ou mito? Belo Horizonte: D’Plácido, 2014.

JABUR, Gilberto Haddad. Liberdade de pensamento e direito à vida privada: conflitos entre direitos da personalidade. São Paulo: Revista dos Tribunais, 2000.

JENIKE-GODSHALCK, Jesse L. "Actual malice" is not Actually Malice: Clarifying and Solving One of the Supreme Court's Enduring Paradoxes. Disponível em:

$<$ https://docplayer.net/36021257-Actual-malice-is-not-actually-malice-clarifying-andsolving-one.html>. Acesso em: 2 jun. 2018.

LIDSKY, Lyrissa Barnett; WRIGHT, George. Freedom of the Press: A Reference Guide to the United States Constitution. [S.1.]: Greenwood, 2004.

LIMA, Alvino. Culpa e risco. 2. ed. São Paulo: Revista dos Tribunais, 1998.

LISBOA, Roberto Senise. Responsabilidade civil nas relações de consumo. São Paulo: Revista dos Tribunais, 2000.

LOPEZ, Teresa Ancona. Princípio da precaução e evolução da responsabilidade civil. São Paulo: Quartier Latin, 2010.

LOUREIRO, Francisco Eduardo. Responsabilidade civil dos veículos de comunicação por atos de terceiros. In: SILVA, Regina Beatriz Tavares da; SANTOS, Manoel J. Pereira dos (Coords.). Responsabilidade civil na internet e nos demais meios de comunicação. São Paulo: FGV; Saraiva, 2007. p. 447-485.

TIMM, Luciano Benetti. Os grandes modelos de responsabilidade civil no direito privado: da culpa ao risco. In: NERY JÚNIOR, Nelson; NERY, Rosa Maria de Andrade. Doutrinas essenciais: responsabilidade civil. 2. tir. São Paulo: Revista dos Tribunais, 2010. v. 1. p. 289-310. 
LUNA, Nevita Maria Pessoa de Aquino Franca Luna; SANTOS, Gustavo Ferreira. Liberdade de expressão e discurso do ódio no brasil. Revista Direito e Liberdade - RDL, v. 16, n. 3, p. 227-255, set./dez. 2014.

MARX, Karl. Liberdade de imprensa. Tradução de Cláudia Schilling e José Fonseca. Porto Alegre: L\&PM Pocket, 2006. Disponível em:

$<$ http://resistir.info/livros/liberdade_de_imprensa.pdf $>$. Acesso em: 2 jul. 2018.

McCRAW, David E. Press Freedom and Private People: The Life and Times (and Future) of Chapadeau v. Utica Observer-Dispatch. Albany Law Review, v. 74.2, p. 841-868, Winter 2011.

MEIRA, Rafael Correia. Curso de direito romano. 1. ed. São Paulo: Saraiva, 1983.

MEIRA, Silvio Augusto de Bastos. Instituições de direito romano. São Paulo: Max Limonad, 1968.

MELO, Patrícia Bandeira. Um passeio pela história da imprensa: o espaço público dos grunhidos ao ciberespaço. Revista Comunicação \& Informação - Faculdade de Comunicação e Biblioteconomia da Universidade Federal de Goiás, v. 8, n. 1, p. 26-38, jan./jun. 2005. Disponível em:

$<$ http://www.fundaj.gov.br/geral/artigo_passeio_historia_imprensa.pdf $>$. Acesso em: 2 jun. 2018.

MENDES JÚNIOR, José Ribamar. Os direitos da personalidade e a liberdade de imprensa: a condenação antecipada do acusado ante a exposição massificada da mídia. Revista ESMAT, v. 7, n. 9, p. 33-50, jun. 2016.

MIRANDA, Darcy Arruda. Comentários à Lei de Imprensa: Lei 5.250, de 1967 sobre a liberdade de manifestação do pensamento e da informação. 3. ed. rev. e atual. São Paulo: Revista dos Tribunais, 1995.

MIRANDA, Darcy Arruda. Dos abusos da liberdade de imprensa. São Paulo: Revista dos Tribunais, 1959.

MORAES, Maria Celina Bodin de. Honra, liberdade de expressão e ponderação.

Civilistica.com, Rio de Janeiro, v. 2, n. 2, abr./jun. 2013. Disponível em:

$<$ http://civilistica.com/honraliberdade-de-expressao-e-ponderacao/ $>$. Acesso em: 28 jun. 2018.

MORAES, Maria Celina Bodin de. Risco, solidariedade e responsabilidade objetiva. In: TEPEDINO, Gustavo; FACHIN, Luiz Edson (Coords.). O direito e o tempo: embates jurídicos e utopias contemporâneas - estudos em homenagem ao professor Ricardo Pereira de Lira. Rio de Janeiro: Renovar, 2008. p. 847-881.

MORATO, Antonio Carlos; CICCO, Maria Cristina de. Direito ao esquecimento: luzes e sombras. In: SILVEIRA, Renato de Mello Jorge; GOMES, Mariângela Gama de Magalhães (Orgs.). Estudos em homenagem a Ivette Senise Ferreira. São Paulo: LiberArs, 2015. p. 77-102. 
NOBRE, Freitas. Comentários à Lei de Imprensa: lei n. 5250, de 09-02-1967. 3. ed. São Paulo: Saraiva.1985.

NUNES JÚNIOR, Vidal Serrano. A proteção constitucional da informação e o direito à crítica jornalística. São Paulo: FTD, 1997.

ORGANIZAÇÃO DAS NAÇÕES UNIDAS. Declaração dos Direitos Humanos. Disponível em:

$<$ http://www.stf.jus.br/portal/cms/verNoticiaDetalhe.asp?idConteudo=100499>. Acesso em: 14 abr. 2017.

PATTERSON, L. R. Copyright and "The Exclusive Right" of Authors. Journal of Intellectual Property Law, v. 1, n. 1, Oct. 1993. Disponível em:

$<$ http://digitalcommons.law.uga.edu/jipl/vol1/iss1/5>. Acesso em: 18 fev. 2018

PESSOA, Maurício. O reflexo dos princípios informadores do Código Civil e das cláusulas gerais na responsabilidade civil: a cláusula geral da responsabilidade objetiva. In: NERY, Rosa Maria de Andrade; DONNINI, Rogério (Coords.). Responsabilidade civil: estudo em homenagem ao professor Rui Geraldo Camargo Viana. São Paulo: Revista dos Tribunais, 2009. p. 398-416.

PIZARRO, Ramon Daniel. Responsabilidad civil de los medios massivos de comunicación: danos por noticias inexactas o agraviantes. Buenos Aires: Hammurabi. 1991.

REALE JÚNIOR, Miguel. Eu não disse? O Estado de S.Paulo, São Paulo, Espaço Aberto, p. A2, 6 jun. 2009. Disponível em: <http://opiniao.estadao.com.br/noticias/geral,eu-naodisse,383229>. Acesso em: 2 jan. 2017.

REALE JÚNIOR, Miguel; DOTTI, René Ariel. Um estatuto da liberdade de imprensa. Folha de S.Paulo, São Paulo, Opinião, 11 mar. 2008. Disponível em: $<$ http://www1.folha.uol.com.br/fsp/opiniao/fz1103200808.htm $\geq$. Acesso em: 3 jan. 2017.

RIO DE JANEIRO (estado). Primeiro Tribunal de Alçada. Apelação n. 63.355. $1^{\text {a }}$ Câmara. Relator: Juiz Julio da Rocha Almeida Apelante: Bloch Editores S/A. Apelada: Anna Paula de Souza. Rio de Janeiro. Data de julgamento: 12/05/1982. v.u. RT 576/249.

RIO DE JANEIRO (estado). Tribunal de Justiça do Rio de Janeiro. Apelação Cível no 2005.001.06. Décima Sétima Câmara Cível. Rio de Janeiro, 28 set. 2005. Disponível em: $<$ http://www1.tjrj.jus.br/gedcacheweb/default.aspx?UZIP=1\&GEDID=00037DC6D88759 4702BD9CB53943E27E0014CBA8C3233F02>. Acesso em: 8 jul. 2018.

RIO DE JANEIRO (estado). Tribunal de Justiça. Apelação Cível no 001329345.1994.8.19.0001. Sexta Câmara Cível. Rio de Janeiro, 18 ago 2010. Disponível em: $<$ http://www1.tjrj.jus.br/gedcacheweb/default.aspx?UZIP=1\&GEDID=000308222CF366B 04A0A33C8DFF736692CAA00C4024D0B26>. Acesso em: 8 jul. 2018.

RIO DE JANEIRO (estado). Tribunal de Justiça. Apelação Cível no 002662006.2008.8.19.0021. Décima Segunda Câmara Cível. Rio de Janeiro, 14 jan. 2014. Disponível em: 
$<$ http://www1.tjrj.jus.br/gedcacheweb/default.aspx?UZIP=1\&GEDID=0004B82507E9B4 A8B6D6F289AB881F5E8D9AC503093C1B08\&USER=>. Acesso em: 8 jul. 2018.

RIO DE JANEIRO (estado). Tribunal de Justiça. Apelação Cível no 2004.001.29.242. Décima Primeira Câmara Cível. Rio de Janeiro, 21 fev. 2005. Disponível em: $<$ http://www1.tjrj.jus.br/gedcacheweb/default.aspx?UZIP=1 \&GEDID=00032078B35E923 955F65BB2D732681E5CFBF965C31F2D06\&USER=>. Acesso em: 8 jul. 2018.

RIO DE JANEIRO (estado). Tribunal de Justiça. Apelação no 4743/89. 4 a Câmara Cível. Rio de Janeiro, 20 fev. 1990. Disponível em:

$<$ http://www1.tjrj.jus.br/gedcacheweb/default.aspx?UZIP=1\&GEDID=000303E7CB37AE 7A3F7A2201DFBEF2B30C254EC40245084E>. Acesso em: 11 jun. 2018.

SANTA CATARINA. Tribunal de Justiça. Processo Criminal no 130. Tribunal Pleno. Florianópolis, 22 dez. 1982. RT 572/374, jun. 1983.

SANTOS, Antonio Jeová. Dano moral indenizável. 4. ed. rev., ampl. e atual. de acordo com o novo Código Civil. São Paulo: Revista dos Tribunais, 2003.

SÃO PAULO (estado). Tribunal de Alçada Criminal. Apelação no 253.849. $8^{\text {a }}$ Câmara. São Paulo, 13 maio 1982. RT 571/357, jun. 1983.

SÃO PAULO (estado). Tribunal de Alçada Criminal. Apelação no 509.935-3. $11^{\text {a }}$ Câmara. São Paulo, 27 jun. 1988. RT 636/309, out. 1988.

SÃO PAULO (estado). Tribunal de Justiça de São Paulo. Apelação Cível com Revisão no 425.039.4/1-00. Quarta Câmara de Direito Privado. São Paulo, 29 maio 2008. Disponível em: $<$ https://esaj.tjsp.jus.br/cjsg/getArquivo.do?cdAcordao $=2649099 \&$ cdForo $=0>$. Acesso em: 8 jul. 2018.

SÃO PAULO (estado). Tribunal de Justiça de São Paulo. Apelação Cível com Revisão no 504.265-4/8-00. Primeira Câmara "A" de Direito Privado. São Paulo, 14 ago. 2008. Disponível em:

$<$ https://esaj.tjsp.jus.br/cjsg/getArquivo.do?cdAcordao=3229149\&cdForo=0 $>$. Acesso em: 8 jul. 2018.

SÃO PAULO (estado). Tribunal de Justiça de São Paulo. Apelação com Revisão no 430.887-4/2-00. Quarta Câmara de Direito Privado. São Paulo, 24 ago. 2006. Disponível em:

$<$ https://esaj.tjsp.jus.br/cjsg/getArquivo.do? conversationId=\&cdAcordao $=1033103 \&$ cdFor $\mathrm{o}=0 \&$ uuidCaptcha $=$ sajcaptcha_8e34a36322c34b7297b6080c22471a9d\&vlCaptcha $=$ fczmn \&novoVlCaptcha=>. Acesso em: 8 jul. 2018.

SÃO PAULO (estado). Tribunal de Justiça de São Paulo. Apelação com Revisão no 436.441-4/1. Quarta Câmara de Direito Privado. São Paulo, 13 dez. 2007. Disponível em: $<$ https://esaj.tjsp.jus.br/cjsg/getArquivo.do? conversationId=\&cdAcordao=2441972\&cdFor $\mathrm{o}=0 \&$ uuidCaptcha $=$ sajcaptcha_8760b55399c64050a49f7bfed5da87aa\&vlCaptcha $=$ wdjmu \&novoVlCaptcha=>. Acesso em: 8 jul. 2018. 
SÃO PAULO (estado). Tribunal de Justiça de São Paulo. Apelação no 002177676.2005.8.26.0068. Quarta Câmara de Direito Privado. São Paulo, 28 maio 2015.

Disponível em:

$<$ https://esaj.tjsp.jus.br/cjsg/getArquivo.do?cdAcordao $=8509501 \&$ cdForo $=0>$. Acesso em: 9 jul. 2018.

SÃO PAULO (estado). Tribunal de Justiça. [Apelação] n. 1.728. Campinas. Apelante: Joaquim de Castro Tibiriçá. Apelado: Joaquim de Souza Ribeiro. $3^{\circ}$ Ofício. RT 113/756.

SÃO PAULO (estado). Tribunal de Justiça. Apelação Cível com revisão no 013715969.2006.8.26.0100. Oitava Câmara de Direito Privado. São Paulo, 29 fev. 2012. Disponível em:

$<$ https://esaj.tjsp.jus.br/cjsg/getArquivo.do?cdAcordao $=5720796 \&$ cdForo=0 $>$. Acesso em: 9 jul. 2018.

SÃO PAULO (estado). Tribunal de Justiça. Apelação Cível com revisão no 415.472.4/900. Quarta Câmara de Direito Privado. São Paulo, 13 dez. 2007. Disponível em: $<$ https://esaj.tjsp.jus.br/cjsg/getArquivo.do?cdAcordao $=2432002 \&$ cdForo $=0>$. Acesso em: 8 jul. 2018.

SÃO PAULO (estado). Tribunal de Justiça. Apelação Cível no 355.108.4/2-00. Quarta Câmara de Direito Privado. São Paulo, 17 nov. 2005. Disponível em:

$<$ https://esaj.tjsp.jus.br/cjsg/getArquivo.do? conversationId=\&cdAcordao $=2046075 \& \mathrm{cdFor}$ $\mathrm{o}=0 \&$ uuidCaptcha $=\& v 1$ Captcha $=$ bks\&novoVlCaptcha $=>$. Acesso em: 8 jul. 2018.

SÃO PAULO (estado). Tribunal de Justiça. Apelação n. 155.152. Birigui. Apelantes: Mario Crem dos Santos e Natal M. Mazucatto. Apelados: os mesmos. RT 375/137.

SÃO PAULO (estado). Tribunal de Justiça. Apelação n. 156.760. Capital. Apelante: Empresa Jornalística São Paulo Shimbum S/A. Apelada: Empresa Cine Niteroi S/A. RT $385 / 119$.

SÃO PAULO (estado). Tribunal de Justiça. Apelação n. 170.040. Capital. Apelante: Cláudio de Freitas Carpenter Ferreira. Apelada: Empresa Jornalística Diário Popular S/A. RT 404/140.

SÃO PAULO (estado). Tribunal de Justiça. Apelação n. 24-1. Capital. Apelante: Jacintho Figueira Júnior. Apelada: Editora Abril Ltda. RT 546/59.

SÃO PAULO (estado). Tribunal de Justiça. Apelação n. 327.719. Capital. Apelante: Tarso de Castro. Apelado: Jânio Quadros. Presidente: Juiz Gofredo Mauro, Fernandes Braga e Canguçu de Almeida. 26 abr. 1983.

SÃO PAULO (estado). Tribunal de Justiça. Apelação n. 4.357-1. Capital. Apelantes: Empresa Folha da Manhã S/A, Cia. Paulista Editora de Jornais e Nascippe Calixto. Apelados: os mesmos. RT 547/59.

SÃO PAUlO (estado). Tribunal de Justiça. Apelação n. 60.021-1. $4^{\text {a }}$ Câmara. Relator: desembargador Alves Braga. Data de julgamento: 20/06/1985. RT 600/66. 
SÃO PAULO (estado). Tribunal de Justiça. Apelação n. 61.308. $6^{\text {a }}$ Câmara. Relator: desembargador Camargo Sampaio. Data de julgamento: 13/06/1985. RT 601/88.

SÃO PAULO (estado). Tribunal de Justiça. Apelação n. 69.603. Santos. Apelante: Antonio Peixoto. Apelado: Noé Cardim (Secretaria). RT 231/364.

SÃO PAULO (estado). Tribunal de Justiça. Apelação n⿳0 0036498-81.2013.8.26.0506. Primeira Câmara de Direito Privado. São Paulo, 14 dez. 2017. Disponível em: $<$ https://esaj.tjsp.jus.br/cjsg/getArquivo.do?cdAcordao $=11074006 \&$ cdForo $=0>$. Acesso em: 8 jul. 2018.

SÃO PAULO (estado). Tribunal de Justiça. Apelação no 1000509-49.2015.8.26.027. Quinta Câmara de Direito Privado. São Paulo, 6 jul. 2016. Disponível em: $<$ https://esaj.tjsp.jus.br/cjsg/getArquivo.do?cdAcordao $=9589266 \&$ cdForo $=0>$. Acesso em: 8 jul. 2018.

SÃO PAULO (estado). Tribunal de Justiça. Apelação no 990.10.094668-4. Oitava Câmara de Direito Privado. São Paulo, 25 ago. 2010. Disponível em:

$<$ https://esaj.tjsp.jus.br/cjsg/getArquivo.do? cdAcordao $=4670006 \&$ cdForo $=0>$. Acesso em: 9 jul. 2018.

SÃO PAULO (estado). Tribunal de Justiça. Apelação n 990.10.206787-4. Quarta Câmara de Direito Privado. São Paulo, 21 out. 2010. Disponível em:

$<$ https://esaj.tjsp.jus.br/cjsg/getArquivo.do? cdAcordao $=4780153 \&$ cdForo $=0>$. Acesso em: 9 jul. 2018.

SARMENTO, Daniel. A ponderação de interesses na Constituição Federal. Rio de Janeiro: Lumen Juris, 2002.

SCHREIBER, Anderson. A responsabilidade civil como política pública. In: TEPEDINO, Gustavo; FACHIN, Luiz Edson (Coords.). O direito e o tempo: embates jurídicos e utopias contemporâneas - estudos em homenagem ao professor Ricardo Pereira de Lira. Rio de Janeiro: Renovar, 2008. p. 743-755.

SCHREIBER, Anderson. Novos paradigmas da responsabilidade civil: da erosão dos filtros da reparação à diluição dos danos. 5. ed. São Paulo: Atlas, 2009.

SOUZA, Sérgio Ricardo de. Abuso da liberdade de imprensa e pseudocensura judicial: no sistema luso-brasileiro. Rio de Janeiro: Lumen Juris, 2013.

STOCCO, Rui. Tratado de responsabilidade civil: doutrina e jurisprudência. 8. ed. rev., atual. e ampl. São Paulo: Revista dos Tribunais, 2011.

SUANNES, Adauto. A indenização do dano moral praticado por intermédio dos meios de comunicação. Revista dos Tribunais, São Paulo, v. 744, p. 61-68, out. 1997.

TORRES, José Henrique Rodrigues. A censura à imprensa e o controle jurisdicional da legalidade. Revista dos Tribunais, São Paulo, ano 83, v. 705, p. 24-33, jul. 1994. 
VOLOKH, Eugene. Tort liability and the original meaning of the freedom of speech, press, and petition. Iowa Law Review, v. 96.1, p. 249-256, Nov. 2010.

ZULIANI, Ênio Santarelli. Responsabilidade civil pelos abusos na Lei de Imprensa. In: SILVA, Regina Beatriz Tavares da; SANTOS, Manoel Joaquim Pereira dos (Coords.). Responsabilidade civil na internet e nos demais meios de comunicação. São Paulo: Saraiva, 2007. p. 381-382.

ZULIANI, Ênio Santarelli; BRUNHARI, Andréa de Almeida. Princípios constitucionais e direito de imagem. Revista do Advogado - AASP, v. 32, n. 117, p. 50-75, out. 2012. 


\section{BIBLIOGRAFIA}

AMARAL NETO, Francisco dos Santos. Direito civil: introdução. 6. ed. rev. aum. e atual. de acordo com o novo Código Civil. Rio de Janeiro: Renovar, 2003.

AMARANTE, Aparecida. Responsabilidade civil por dano à honra. 5. ed. rev., atual. e ampl. Belo Horizonte: Del Rey, 2001.

AMPONSAH, Peter N. Libel Law, Political Criticism, and Defamation of Public Figures: The United States, Europe, and Australia. New York: LFB Scholarly, 2004.

ARAUJO, Vaneska Donato de. O lugar da culpa e os fundamentos da responsabilidade civil no direito contemporâneo. In: HIRONAKA, Giselda Maria Fernandes Novaes; FALAVIGNA, Maria Clara Osuna Dias (Coords.). Ensaios sobre responsabilidade civil na pós-modernidade. Porto Alegre: Magister, 2007. p. 407-437.

AZEVEDO, Álvaro Villaça. Jurisprudência não pode criar responsabilidade objetiva, só a lei. Análise das súmulas 341, 489 e 492, do Supremo Tribunal Federal, e 132 do Superior Tribunal de Justiça. Revista dos Tribunais, São Paulo, v. 86, p. 109-128, 1997.

AZEVEDO, Álvaro Villaça. Proposta de classificação da responsabilidade objetiva: pura e impura. Revista dos Tribunais, São Paulo, v. 82, p. 7-11, 1993.

BARBOSA, Rui. A imprensa e o dever da verdade. 2. ed. São Paulo: Com-arte. 1990.

BARETO, Vicente de Paulo. O "admirável mundo novo" e a teoria da responsabilidade. In: TEPEDINO, Gustavo; FACHIN, Luiz Edson (Coords.). O direito e o tempo: embates jurídicos e utopias contemporâneas - estudos em homenagem ao professor Ricardo Pereira de Lira. Rio de Janeiro: Renovar, 2008. p. 995-1018.

BARROSO, Luis Roberto. O direito constitucional e a efetividade de suas normas: limites e possibilidades da Constituição brasileira. Rio de Janeiro: Renovar, 1996.

BASTOS, Celso Ribeiro. Curso de direito constitucional. 22. ed. São Paulo: Saraiva, 2010.

BELTRÃO, Silvio Romero. Direitos da personalidade: de acordo com o Novo Código Civil. São Paulo: Atlas, 2005.

BITELLI, Marcos Alberto Sant'Anna. O direito da comunicação e da comunicação social. São Paulo: Revista dos Tribunais, 2004.

BITTAR, Eduardo C. B.; CHINELLATO, Silmara Juny de Abreu. Estudos de direito de autor, direito da personalidade, direito do consumidor e danos morais. Rio de Janeiro: Forense Universitária, 2002.

BOAS, Regina Vera Villas. Marcos históricos relevantes da história da responsabilidade civil. In: NERY, Rosa Maria de Andrade; DONINI, Rogério (Coords.). Responsabilidade 
civil: estudo em homenagem ao professor Rui Geraldo Camargo Viana. São Paulo: Revista dos Tribunais, 2009. p. 428-447.

BORGES, Roxana Cardoso Brasileiro. Disponibilidade dos direitos da personalidade e autonomia privada. São Paulo: Saraiva, 2005.

CAHALI, Youssef Said. Dano moral. 4. ed. rev., atual. e ampl. São Paulo: Revista dos Tribunais, 2011.

CALDAS, Pedro Frederico. Vida privada, liberdade de imprensa e dano moral. São Paulo: Saraiva, 1997.

CANOTILHO, José Joaquim Gomes. Direito constitucional e teoria da Constituição. 7. ed. Coimbra: Almedina, 2003.

CASTRO, Carlos Alberto Siqueira. A Constituição aberta e os direitos fundamentais. Rio de Janeiro: Forense, 2003.

CAVALIERI FILHO, Sérgio. Programa de responsabilidade civil. 11. ed. rev. e ampl. São Paulo: Malheiros, 2014.

CHINELLATO, Silmara Juny de Abreu. Biografias não autorizadas: liberdade de expressão, outros direitos da personalidade e direito de autor. Cadernos de PósGraduação em Direito: estudos e documentos de trabalho, v. 30, p. 18-37, 2014.

CHINELLATO, Silmara Juny de Abreu. Da responsabilidade civil no Código de 2002: aspectos fundamentais. Tendências do Direito Contemporâneo. In: TEPEDINO, Gustavo; FACHIN, Luiz Edson (Coord.). O direito e o tempo: embates jurídicos e utopias contemporâneas - estudos em homenagem ao professor Ricardo Pereira de Lira. Rio de Janeiro: Renovar, 2008.

CHINELLATO, Silmara Juny de Abreu. Da responsabilidade civil no Código de 2002. In: TEPEDINO, Gustavo; FACHIN, Luiz Edson (Coords.). O direito e o tempo: embates jurídicos e utopias contemporâneas - estudos em homenagem ao professor Ricardo Pereira de Lira. Rio de Janeiro: Renovar, 2008. p. 939-968.

CHINELLATO, Silmara Juny de Abreu. Direito de autor e direitos da personalidade: reflexões à luz do código civil. 2008. 272 f. Tese (Doutorado em Direito) - Faculdade de Direito, Universidade de São Paulo, São Paulo, 2008.

CHINELLATO, Silmara Juny de Abreu. Liberdade de expressão: direitos da personalidade e as biografias não autorizadas. Revista Brasileira de Direito Comparado, v. 44/45, p. 201-237, 2014.

CHINELLATO, Silmara Juny de Abreu. Tendências da responsabilidade civil no direito contemporâneo: reflexos no Código de 2002. In: DELGADO, Mário Luiz; ALVES, Jones Figueirêdo. Questões controvertidas no novo Código Civil. São Paulo: Método, 2003. p. 593-606. 
D’AGOSTINI, Marcos G. Bases filosóficas da responsabilidade civil. In: HIRONAKA, Giselda Maria Fernandes Novaes; FALAVIGNA, Maria Clara Osuna Dias (Coords.). Ensaios sobre responsabilidade civil na pós-modernidade. Porto Alegre: Magister, 2007. p. 267-274.

DAVID, Simone. Responsabilité civile et risque professionnel: thèse pour l'agregation de l'enseignement superieur. Liege: Vaillant Carmanne, 1957.

DE CUPIS, Adriano. Os direitos da personalidade. Tradução de Adriano Vera Jardim e Antonio Miguel Caeeiro. Lisboa: Livraria Moraes, 1961.

DINIZ, Maria Helena. Direito à imagem e sua tutela. In: BITTAR, Eduardo C. B.; CHINELLATO, Silmara Juny de Abreu (Coords.). Estudos de direito de autor, direito da personalidade, direito do consumidor e danos morais: homenagem ao professor Carlos Alberto Bittar. Rio de Janeiro: Forense Universitária, 2002. p. 79-106.

DONNINI, Rogério Ferraz; DONNINI, Oduvaldo. Imprensa livre, dano moral, dano à imagem e sua quantificação à luz do novo Código Civil. São Paulo: Método, 2002.

DONNINI, Rogério. Prevenção de danos e a extensão do princípio neminem laedere. In: NERY, Rosa Maria de Andrade; DONNINI, Rogério (Coords.). Responsabilidade civil: estudo em homenagem ao professor Rui Geraldo Camargo Viana. São Paulo: Revista dos Tribunais, 2009. p. 483-503.

DOTTI, René Ariel. Limites democráticos da liberdade de informação. Consultor Jurídico, 23 jun. 2010. Disponível em: <http://www.conjur.com.br/2010-jun-23/cartaaberta-ministro-marco-aurelio-limites-liberdade-informacao>. Acesso em: 3 jan. 2017.

DOTTI, René Ariel. O diálogo entre a corda e o pescoço. Folha de S.Paulo, São Paulo, Opinião, 13 maio 2009. Disponível em:

$<$ http://wwwl.folha.uol.com.br/fsp/opiniao/fz1305200909.htm $\geq$. Acesso em: 3 jan. 2017.

DWORKIN, Ronald. Freedom's Law: The Moral Reading of the American Constitution. Cambridge, MA: Harvard University Press, 1996.

ESTADOS UNIDOS DA AMÉRICA. Lei da Espionagem. Aprovada em 15 de junho de 1917. Disponível em: < http://www.legisworks.org/congress/65/publaw-24.pdf >. Acesso em: 5 jul. 2018.

FARIAS, Edmilsom Pereira. Liberdade de expressão e comunicação: teoria e proteção constitucional. 2001. 287 p. Tese (Doutorado em Direito) - Centro de Ciências Jurídicas, Universidade Federal de Santa Catarina, Florianópolis, 2001.

FERNANDES NETO, Guilherme. Direito da comunicação social. São Paulo: Revista dos Tribunais, 2004.

FERRAZ JÚNIOR, Tércio Sampaio. Liberdade de opinião, liberdade de informação mídia e privacidade. In: PIOVESAN, Flávia; GARCIA, Maria (Orgs.). Direitos humanos. São Paulo: Revista dos Tribunais, 2011. p. 24-29. 
FERREIRA FILHO, Manoel Gonçalves. Comentários à Constituição brasileira de 1988. 3. ed. atual. São Paulo: Saraiva, 2000.

FERREIRA, Manuel Alceu Affonso. Censura à censura. Revista do Advogado, São Paulo, n. 61, p. 79-81, nov. 2000.

FRANÇA, Rubens Limongi. As raízes da responsabilidade aquiliana. In: NERY JÚNIOR, Nelson; NERY, Rosa Maria de Andrade. Doutrinas essenciais: responsabilidade civil. 2. tir. São Paulo: Revista dos Tribunais, 2010. v. 1. p. 267-287.

GIOVANNINI, Giovanni. Evolução na Comunicação: do sílex ao silício. Rio de Janeiro: Nova fronteira, 1987.

GOLD, Susan Dudley. New York Times Co. v. Sullivan: Freedom of the Press or Libel? Tarrytown, NY: Marshall Cavendish Benchmark, 2007.

GOMES JÚNIOR, Luiz Manoel; OLIVEIRA, Ricardo Alves de. A responsabilidade civil dos órgãos de imprensa e a teoria do risco criado (artigo 927, parágrafo único, do CC/2002). Revista IOB de Direito Civil e Processual Civil, v. 44, p. 90-104, nov./dez. 2006.

GONÇALVES, Carlos Roberto. Responsabilidade civil. 13. ed. São Paulo: Saraiva, 2011.

GONÇALVES, Thiago de Oliveira. Responsabilidade civil pelo exercício da liberdade de imprensa: análise crítica da posição do STF na ADPF 130. Revista do Direito das Comunicações, v. 2, p. 85-114, jul./dez. 2010.

HINDMAN, Elizabeth Blanks. Rights vs. Responsibilities: The Supreme Court and the Media. [S.1.]: Greenwood, 1997.

HIRONAKA, Giselda Maria Fernandes Novaes. Responsabilidade civil: o estado da arte, no declínio do segundo milênio e albores de um tempo novo. In: NERY, Rosa Maria de Andrade; DONNINI, Rogério (Coords.). Responsabilidade civil: estudo em homenagem ao professor Rui Geraldo Camargo Viana. São Paulo: Revista dos Tribunais, 2009. p. 184224.

HIRONAKA, Giselda Maria Fernandes Novaes. Responsabilidade pressuposta. Belo Horizonte: Del Rey, 2005.

IGLESIAS, Sérgio. Responsabilidade civil por danos à personalidade. Barueri: Manole, 2003.

INGELHART, Edward. Press and Speech Freedoms in the World, from Antiquity until 1998: A Chronology. [S.1.]: Greenwood, 1998.

JABUR, Gilberto Haddad. Limitações ao direito à própria imagem no Novo Código Civil. In: DELGADO, Mário Luiz; ALVES, Jones Figueirêdo. Questões controvertidas no novo Código Civil. São Paulo: Método, 2003. p. 11-44. 
KENNEDY, Sheila Suess. Free Expression in America: A Documentary History. [S.1.]: Greenwood, 1999.

LEAO, Assis José. Comunicação social na nova Constituição. Revista da Faculdade de Direito da Universidade Federal de Minas Gerais, Belo Horizonte. v. 33. n. 33, p. 465 80, 1991.

LEWIS, Anthony. Freedom for the Thought That We Hate: A Biography of the First Amendment. New York: Basic Book, 2007.

LOTUFO, Renan. A responsabilidade civil e o papel do juiz no Código Civil de 2002. In: NERY, Rosa Maria de Andrade; DONNINI, Rogério (Coords.). Responsabilidade civil: estudo em homenagem ao professor Rui Geraldo Camargo Viana. São Paulo: Revista dos Tribunais, 2009. p. 428-447.

MACHADO, Antonio Cláudio da Costa; CHINELLATO, Silmara Juny. Código Civil interpretado: artigo por artigo, parágrafo por parágrafo. 7. ed. Barueri: Manole, 2014.

MACHADO, Jónatas Eduardo Mendes. Liberdade de expressão, interesse público e figuras públicas equiparadas. Boletim da Faculdade de Direito [da] Universidade de Coimbra, Coimbra, n. 85, p. 73-109, jan. 2009.

MACHADO, Jónatas Eduardo Mendes. Liberdade de expressão: dimensões constitucionais da esfera pública no sistema social. Coimbra: Coimbra, 2002.

MENDES, Gilmar Ferreira. Colisão de direitos fundamentais: liberdade de expressão e comunicação e direito à honra e à imagem. Revista de Informação Legislativa, Brasília, v. 31, n. 122, p. 297-302, abr./jun. 1994. Disponível em:

$<$ http://www2.senado.leg.br/bdsf/bitstream/handle/id/176193/000487451.pdf > . Acesso em: 2 jun. 2018.

MENDES, Gilmar Ferreira; BRANCO, Paulo Gustavo Gonet. Curso de direito constitucional. 12. ed. São Paulo: Saraiva, 2016.

MONTEIRO FILHO, Carlos Edson do Rêgo. In: TEPEDINO, Gustavo; FACHIN, Luiz Edson (Coords.). O direito e o tempo: embates jurídicos e utopias contemporâneas estudos em homenagem ao professor Ricardo Pereira de Lira. Rio de Janeiro: Renovar, 2008. p. 69-94.

MORAES, Alexandre de. Direito constitucional. 29. ed. São Paulo: Atlas, 2013.

MORAES, Alexandre de. Direitos humanos fundamentais. 10. ed. São Paulo: Atlas, 2013.

MORAES, Maria Celina Bodin de. Danos à pessoa humana: uma leitura civilconstitucional dos danos morais. Rio de Janeiro: Renovar, 2003.

MORATO, Antonio Carlos. Conflito entre direitos da personalidade: direito à intimidade e liberdade de expressão. Revista do Curso de Direito da Universidade São Marcos, São Paulo, v. 1, n. 1, p. 149-171, 2001. 
MORATO, Antonio Carlos. Quadro geral dos direitos da personalidade. Revista da Faculdade de Direito da Universidade de São Paulo, São Paulo, v. 106/107, p. 121-158, jan./dez. 2011/2012. Disponível em:

$<$ http://www.producao.usp.br/bitstream/handle/BDPI/43541/Quadro\%20geral\%20dos\%20 direitos $\% 20 \mathrm{da} \% 20$ personalidade.pdf? sequence=1\&isAllowed=y $>$. Acesso em: 10 mar. 2018.

NOBRE, Freitas. Imprensa e liberdade: os princípios constitucionais e a nova legislação. São Paulo: Summus, 1988.

POLLOCK, Frederik. The Law of Torts. London: Stevens and Sons, 1912.

PORTO, Sérgio José. A responsabilidade civil por difamação no direito inglês. Porto Alegre: Livraria do Advogado, 1995.

ROIG, D. Francisco Javier Ansuátegui. Origenes doctrinales de la libertad de la expresion. Disponível em: <https://e-archivo.uc3m.es/handle/10016/15830>. Acesso em: 10 jan. 2018.

SILVA, Américo Martins da. O dano moral e sua reparação civil. 4. ed. rev., atual. e ampl. São Paulo: Revista dos Tribunais, 2012.

SILVA, Andre Chaves de Melo. O paradoxo da cultura de massas: democracia em crise e censura disfarçada. Revista Brasileira de Direito Constitucional, São Paulo. n. 3. p. 32534, jan./jun. 2004.

SILVA, José Afonso da. Curso de direito constitucional positivo. 37. ed. rev. e atual. até a Emenda Constitucional n. 76 de 28.11.2013. São Paulo: Malheiros, 2014.

SILVA, Regina Beatriz Tavares da; SANTOS, Manoel J. Pereira dos (Coords.). Responsabilidade civil na internet e nos demais meios de comunicação. São Paulo: FGV; Saraiva, 2007.

SILVA, Wilson Melo da. Responsabilidade sem culpa. 2. ed. São Paulo: Saraiva, 1974. SODRÉ, Nelson Werneck. História da imprensa no Brasil. 4. ed. atual. Rio de Janeiro: Maud, 1999.

SOUZA, Rabindranath Valentino Aleixo Capello de. O direito geral de personalidade. Coimbra: Coimbra, 1995.

SUSTEIN, Cass R. Democracy and the Problem of Free Speech. New York: Free Press, 1995.

TEPEDINO, Gustavo. A evolução da responsabilidade civil no direito brasileiro e suas controvérsias na atividade estatal. In: TEPEDINO, Gustavo. Temas de direito civil. 4. ed. rev. e atual.Rio de Janeiro: Renovar, 2008. 
TEPEDINO, Gustavo. A tutela da personalidade no ordenamento civil-constitucional brasileiro. In: TEPEDINO, Gustavo. Temas de direito civil. 2. ed. rev. atual. Rio de Janeiro: Renovar, 2001.

VASCONCELLOS, Pedro Pais. Proteção de dados pessoais e direito à privacidade: direito da sociedade da informação. Coimbra: Coimbra, 1999. v. 1.

VIEIRA, Patricia Ribeiro Serra. O fenômeno da objetivação da responsabilidade da Lei Civil brasileira. In: TEPEDINO, Gustavo; FACHIN, Luiz Edson (Coords.). O direito e o tempo: embates jurídicos e utopias contemporâneas - estudos em homenagem ao professor Ricardo Pereira de Lira. Rio de Janeiro: Renovar, 2008. p. 883-902.

ZANNONI, Eduardo A.; BÍSCARO, Beatriz R. Responsabilidad de los medios de prensa. Buenos Aires: Astrea, 1993.

ZULIANI, Ênio Santarelli. Aguiar Dias e a evolução da responsabilidade civil no direito brasileiro. In: LEITE, Eduardo de Oliveira (Coord.). Responsabilidade civil. Rio de Janeiro: Forense, 2006. v. 6.

ZULIANI, Ênio Santarelli. Comentários à Lei de Imprensa. Coordenação de Luiz Manoel Gomes Júnior. São Paulo: Revista dos Tribunais, 2007. 